\title{
Topkapı Sarayında III. Ahmet Kütüphanesi ve Çini Bezemeleri
}

\section{Zekiye UYSAL*}

\begin{abstract}
Öz
İstanbul'un fethinden bir süre sonra Sultan II. Mehmet tarafindan yaptırılan Topkapı Sarayı (M.1458-1478); 19. Yüzyıl ortalarına kadar diğer sultanların eklettikleri binalar ve onarımlarla son şeklini almıştr. Saraya yeni bölümler yaptran sultanlardan birisi olan III. Ahmet (M.1703-1730), harem bölümüne bir yemiş odası ve üçüncü avluya bir kütüphane inşa ettirmiştir.Osmanlı tarihi içinde onun saltanat dönemi "Lâle devri" olarak tanınır. Bu dönemin önde gelen örneklerinden olan III. Ahmet Kütüphanesi'nin mimarının Beşir Ağa olduğu ileri sürülür.Üçüncü avludaki Havuzlu köşkün yerine yaptrılan kütüphane (H.1131/M.1719); bodrum kat üzerine oturan kubbeli sofa ve buna açılan üç eyvandan oluşur.Giriş kanadında üç bölmeli bir revak ve revakın cephesine bitişik bir çeşme ve revakın orta kısmına bakan küçük boyutlu ikinci bir çeşme yer alır. Yapı M.1856 yılındaki Enderun yangınında hasar görmüş, yangından sonraki onarımda giriş cephesinde bazı değişiklikler yapıımıştr. Kütüphanenin bu yangından önceki görünümü Levnî'nin minyatürlerinde, Bartlett'in gravüründe ve bir tabloda izlenebilmektedir. Cumhuriyet döneminde 1924-1999 yılları arasında birkaç kez onarılan yapı, en son 2014-2018 yılları arasında restore edilmiştir.

III. Ahmet Kütüphanesi; Osmanlı köşk tiplerinden ilham alan bodrum katlı planı, mermer malzemeyle kaplı anıtsal cepheleri, ilginç çeşme yapılarıyla ilişkilendirilmiş revakı; zengin alçı (ştuko) ve çinilerle bezeli iç mekanları, sedef kakmalı pencere kepenkleri, üst sıra pencerelerinin revzenleri ve iç mekanda mermer sütunlar, başlıklar ve bunların üst kısımlarındaki plastik ögeleriyle Lâle devrini en gösterişli biçimde yansıtan yapılardan birisidir. Fakat iç cepheleri tavana kadar kaplayan çinilerin Lâle devrinden önceye ait yapılardan getirildikleri bilinmektedir. Bu çinilerin büyük çoğunluğu 17. yüzyıl ilk yarısına tarihlenebilirler. Bir grup çini ise üslûp açısından 17. yüzyılın ikinci yarısına verilebilirler. Lâle devrinin simge yapılarından birisi olan III. Ahmet Kütüphanesi'nde Klâsik üsluptaki çinilerin kullanılması ilginç bir tezat oluşturmaktadır.
\end{abstract}

Anahtar Kelimeler: Topkapı Sarayı, Lale Devri, III.Ahmet Kütüphanesi, Çini.

\section{The Library of Sultan Ahmet III and Tile Decoration in Topkapı} Palace

\begin{abstract}
Topkapı Palace (M.1458-1478), the construction of which was ordered by Mehmed the Conqueror a few years after the conquest of Istanbul, took its final form with the restorations and buildings added by other sultans until the midst of the 19th century. Ahmet III (M.1703-1730), one of the sultans who added new sections to the palace, ordered the construction of a fruit room in the palace and a library in the third courtyard. His reign is known as the "Tulip Era" in the Ottoman history. It is claimed that the architect of the Library of Ahmet III, one of the leading examples of this period, is Beşir Aga. The library, which was built in the third courtyard in place for the Pool Pavilion (H.1131/M.1719), consists of a domed sofa on the basement and three iwans opening here. On the entrance to this section, there is a portico with three sections, a fountain adjacent to the
\end{abstract}

Doç.Dr. Zekiye UYSAL, Çanakkale Onsekiz Mart Üniversitesi Fen-Edebiyat Fakültesi Sanat Tarihi Bölümü, zuysal@comu.edu.tr 
front of the portico and a small-sized second fountain facing the midsection of the portico. The structure was damaged during the Enderun fire occurred in M.1856 and certain changes were made in its entrance section in the restoration following the fire. The appearance of the library before this fire can be observed in Levni's miniatures, in Bartlett's engraving and in a painting. The structure, which was restored several times between 1924-1999 during the Republic period, was most recently restored between 2014-2018.

The Library of Ahmet III is one of the structures reflecting the Tulip Era in the most spectacular way with its plan with the basement floor inspired by the Ottoman pavilion types, monumental facades covered with marble materials, portico associated with in teresting fountain structures, interiors decorated with rich stuccos and tiles, window shutters with mother-of-pearl inlaid, fresco windows and marble pillars inside, window titles and plastic elements on their upper parts. However, it is known that the tiles covering the interior facades up to the ceiling were brought from the buildings belonging to the period before theTulip Era. The majority of these tiles can be dated back to the first half of the 17th century. A group of tiles can be dated to the second half of the 17th century. The use of the tiles in the classical style in the Library of Ahmet III, which is one of the symbols of theTulip Era, creates an interesting contrast.

Keywords: Topkapı Palace, Tulip Era, III.Ahmet Library, Tile.

\section{Gíriş}

İstanbul'un fatihi Sultan II. Mehmet tarafindan Ayasofya'nın arkasındaki burun üzerine M.1458-1478 yılları arasında inşa edilen Topkapı Sarayı; 19. yüzyıl ortalarına kadar diğer Osmanlı sultanlarının ilaveleri ve onarımlarıyla şekillenmiştir. ${ }^{1}$ Sûr-ı Sultânî’nin içinde peşpeşe dizilen avlular çevresindeki binalardan oluşan saray külliyesinde, diğer sultanların eklediği binalar arasında Sultan III. Ahmet'e ait olanlar da vardır. Onun M.1703-1730 yılları arasını kapsayan saltanat döneminde sarayın yapı envanterine eklenen birimlerin içinde Yemiş Odası ile kütüphane binası hemen dikkati çekerler. Bunlardan, Enderûn Kitaplığı da denilen kütüphane yapısı, mimarisi kadar bezemeleriyle de göz kamaştırır.

Yapı, Topkapı Sarayı'nı konu edinen kitaplarda ve Osmanlı kütüphane mimarlığını ele alan çalışmalarda mimari açıdan ele alınmış olmasına rağmen; özellikle bezemeleri bakımından yeterince irdelenmemiş durumdadır. Bundan hareketle hazırladığımız makalede kütüphanenin inşa süreci, mimarisi ve çini süslemelerinin irdelenerek değerlendirilmesi amaçlanmıştır. Çalışmamız 2015 ve 2018 yıllarında Topkapı Sarayı'nda yaptığımız yerinde incelemeye ve literatür araştırmasına dayanmaktadır. Makalede yer alan fotoğraf ve çizimlerin kaynakları alt yazılarında gösterilmiştir. Diğer fotoğraflar tarafimızdan çekilmiştir. Kütüphanenin taş ve alçı bezemeleri de ayrı bir araştırma konusu teşkil edecek kadar önemlidir. Bu nedenle yapının taş ve alçı bezemelerini ayrı makaleler halinde ele almayı düşünüyoruz. ${ }^{2}$

III.Ahmet Kütüphanesi, Topkapı Sarayı'nın Enderun bölümünde Enderun Meydanı diye bilinen üçüncü avluda yer alır. ${ }^{3}$ (Şek.1) Kütüphane, Bâbü's-saade'den geçilen Arz Odası'nın hemen kuzeydoğusuna, eskiden burada mevcut olan Havuzlu Köşk'ün yerine

1 Necdet Sakaoğlu, Tarihi, Mekanları, Kitâbeleri ve Anıları ile Saray-ı Hümayun,Topkapı Sarayı, Denizbank Yayını, İstanbul 2002, s.14;Gülru Necipoğlu, 15. 16. yüzyılda Topkapı Sarayı: Mimari Tören ve iktidar, Çev.:R.Sezer,Yapı Kredi Yayınları, İstanbul 2007, s.27-30.

2 III.Ahmet Kütüphanesi araştırması için izin vererek gerekli kolaylığı gösteren Topkapı Sarayı Müze Müdürlüğü'ne ve yardımları için müze personeline teşekkür ediyorum. Ayrıca çalışmanın değişik aşamalarındaki katkıları ve metnin kontrolü için Prof.Dr. Ali Osman Uysal’a teşekkür ederim. Bkz.; Doğan Kuban, Osmanlı Mimarisi, YEM Yayınları, İstanbul 2007,s.414. 
yapılmıştır. Revak cephesine bitişik çeşme ile bunun sırtına bitişik olup, revakın ortasına yönelik küçük çeşme de kütüphaneyle birlikte tasarlanmış görünmektedir.

III.Ahmet Kütüphanesi hakkındaki literatür araştırılırken, öncelikle Lale devrinin tarihi kaynaklarına bakmak faydalı olacaktır. Zirâ bu dönemin önemli tarihçilerinden Silahdar Fındıklııı Mehmed Ağa'nın Nusretname adlı eserinde ve Vak'anüvis Raşid Mehmed Efendi'nin Târih-i Râşid adıyla bilinen kitabında kütüphanenin inşa gerekçesi ve inşası hakkında önemli bilgiler bulunmaktadır.4 Dönemin ünlü nakkaşı Levnî'nin, Seyyîd Vehbî'nin Surnâmesine yaptığı minyatürlerden birisinde kütüphanenin bir tasviri yer alır. ${ }^{5}$ Ayrıca yapının ve önündeki çeşmenin kitâbeleri, yapının inşası sırasındaki yazışmalar ve Topkapı Sarayı arşivinde muhafaza edildiği anlaşılan inşaat defterlerinde yapılaşma sürecine ilişkin ayrıntılar, ilk inşa aşamasına dair kaynaklar arasında anılabilirler. ${ }^{6} 19$. yüzyılın ilk yarısında, Miss Pardoe'nun İstanbul ve Topkapı sarayı hakkındaki eserlerini resimleyen W.H.Bartlett'in Enderun avlusunda kütüphaneyi gösteren gravürü ile 19. yüzyılın sonlarına ait olup Topkapı Arşivinde bulunan H.1308- M.1890 tarihli saray planı, kütüphanenin tarihi süreci açısından değer taşıyan belgeler arasında öne çıkarlar.7

20.yüzyıl ve günümüze ait araştırma ve yayınlar arasında Sedat Hakkı Eldem ile Feridun Akozan`ın birlikte hazırladıkları "Köşkler ve Kasırlar I-II " adlı eserleri öncelik taşırlar.8 Bu kitaplarda hem Topkapı Sarayı'nın inşa dönemleri hem de Enderun Kütüphanesi (III. Ahmet Kütüphanesi) mimarisi hakkında ayrıntılı rölöveler ve yapım aşaması, onarımlar hakkında tarihi bilgiler bulunmaktadır. Ayrıca yapıyı doğrudan ya da dolaylı olarak ele alan lisansüstü tez çalışmaları da hazırlanmıştır. ${ }^{9}$

Bunların dışında birçok makale ve kitapta daha yapıya değinildiği görülür. Bunlar arasında yapıyı doğrudan ilgilendirenlere öncelik verilerek, gerekli görülen diğer araştırma ve yayınlardan da yararlanma yoluna gidilmiştir.

4 Silahdar Fındıklılı Mehmet Ağa, Nusretnâme,C.Il.,Sadeleştiren: İsmet Parmaksızoğlu, Milli Eğitim Basımevi, İstanbul 1966, s.24-25; Râşid Mehmed Efendi, Târihi Râşid ve Zeyli, C.II, Haz: Abdülkadir Özcan v.d., İstanbul 2013, s.1150.

5 Gül İrepoğlu, Levnî: Nakış,Şiir, Renk, T.C. Kültür Bakanlı̆̆ı Yayını, İstanbul 1999,s.22;Esin Atıl, Levni ve Surname Bir Osmanlı Şenliğinin Öyküsü, Çev:Zeynep Rona, Koçbank Yayınları, İstanbul 1999, s.24.

6 Bkz. Ahmet Refik, OnikinciAsr-ı Hicrîde İstanbul Hayat, (1689-1785), Enderun Kitâbevi, 2.Baskı, İstanbul 1988, s.64; Sedat Hakkı Eldem, Köşkler ve Kasırlar,II, Devlet Güzel Sanatlar Akademisi, İstanbul 1974, s.195.

7 Julia Pardoe, Sultanlar Şehri İstanbul,Çev: M.Banu Büyükkal, Türkiye İ̧̧ Bankası Kültür Yayınları, İstanbul 2010, s.553; Sedat Hakkı Eldem-Feridun Akozan, Topkapı Sarayı, Kültür ve Turizm Bakanlığı Yayını, İstanbul 1982,Lev.65-66.

8 Sedat Hakkı Eldem-Feridun Akozan, Köşkler ve Kasırlar,l, Devlet Güzel Sanatlar Akademisi, İstanbul 1969, s.99-107; Köşkler ve Kasırlar, II, s.195.

9 Alime Şahin,İstanbul'daki Osmanlı Dönemi Kütüphaneleri Üzerine Bir Araştırma ve $\mathrm{Hacl} \mathrm{Beşir}$ Ağa Kütüphanesi, (Yıldız Teknik Üniversitesi, Fen Bilimleri Enstitüsü, Yayınlanmamış Yüksek Lisans Tezi),İstanbul 1997;Ümran Karahasan, Topkapı Sarayı Müzesi Cumhuriyet Dönemi Restorasyonları, (Yıldız Teknik Üniversitesi, Fen Bilimleri Enstitüsü, Yayınlanmamış Doktora Tezi), İstanbul 2005; Asuman Karabudak, 18.yüzyıl Tarihi Yarımada Kütüphane Yapıları Koruma Sorunları ve Öneriler,(Mimar Sinan Üniversitesi Fen Bilimleri Enstitüsü Yayınlanmamış Yüksek Lisans Tezi), İstanbul 2006;Soner Şahin, Değişim Sürecinde Osmanlı Mimarlığı, III.Ahmet ve I.Mahmut Dönemi(1703-1754),(İstanbul Teknik Üniversitesi, Fen Bilimleri Enstitüsü, Yayınlanmamış Doktora Tezi), İstanbul 2009; Gülçin Canca, Bir Geçiş Dönemi Olarak İstanbul'da 3.Ahmet Devri,(Mimar Sinan Güzel Sanatlar Üniversitesi, Sosyal Bilimler Enstitüsü, Yayınlanmamış Doktora Tezi), İstanbul 1999. 


\section{INŞA TARIHI VE GEÇIRDIĞi ONARIMLAR:}

Yapının inşa tarihi hakkında kapısı üzerindeki kitâbeden bilgi edinilmekle birlikte; kütüphane inşasının nedenleri ve sürece ilişkin ayrıntılar esas olarak dönemin tarih kitaplarında nakledilmektedir.Bunlardan vak'anüvis Râşid Mehmed Efendi; Osmanlı devletinin kuruluşundan beri çeşitli yollarla saraya girip Enderûn-ı Saray-ı Hümâyûn'da vâki Hazine-i âmirede toplanmış olan sayısız nefis kitaplar ve lâtif nüshaların dolaplarda perişan, bakımsız ve ilgiden uzak kalmasını uygun görmeyen Sultan Ahmet'in Enderûn- Hümâyûn'da bir kütüphane binasına ve saraydaki tüm kitap ve nüshaların burada toplanmasına karar verdiğini kaydeder. Râşid Efendi'ye göre sultan; sadrazamına bir ferman göndererek gerekli amele ve malzemelerin sağlanmasını ister. Bundan sonra sadrazam, Şeyhülislam, sadreyn ve nakibü'l-eşref efendiler saraya davet edilerek, bizzat padişahın da taş koyması ile temel atma töreni gerçekleştirilir. ${ }^{10}$ Râşid tarihine göre kütüphane, bir tarafi Hâne-i Hassa, bir tarafi Surre Odası ve bir tarafi Seferli Odası ve Arz Odasına bakan alana, buradaki ikiyüz yıllık kasrın yerine mermer duvarlar üzerine inşa edilmeye başlanır. ${ }^{11}$

Silahdar Fındıklılı Mehmed Ağa ise Nusretnâme'de bu girişimi şöyle anlatır: "Sultan Ahmed kendisinin okuma merakı yanında saray mensuplarının da okumaya düşkünlüklerini görünce, l̇ç Hazine ile Has Oda hazinesinde ve Harem-i Hümâyûnda dağınık yerlerde bulunan kıymetli kitapların bir yerde toplanmasını sağlamak amacıyla sarayda, taştan ve güzel bir kütüphâne yapılmasını istemişti. Bunun üzerine Arz odasının arkasına düşen Sultan II. Selim'in yaptırmış olduğu beyaz mermer havuz ile on iki somaki mermer direkle tutturulan tekne kubbeyle örtülü köşkten ötürü Havuzlu Bağçe adıyla anılan yer,bu kütüphâne için uygun görülmüş ve anılan köşkle havuzun yıktırılması emredilmişti. Birkaç gün içinde, söz konusu köşk ve havuz kaldırılarak kütüphanenin yeri hazırlanmışt. Padişah, kütüphanenin temelini kazmak için, dedesi Sultan I. Ahmed'in At meydanında yapttrdığı câminin temelini açarken kullandığı ve o zamandan beri Has Odada saklanmakta olan altın kazmayı kullanmış, Havuz bağçesine gelerek Kilerli ve Seferli odalarının hocalarına yaptırdığı bir duadan sonra, önce kendisi,sonra büyük oğlu şehzâde Süleyman, onun arkasından ise Arz ağaları, mimarlar ve duvarcı ustaları temeli kazmaya başlamışlardı. Kütüphanenin temelleri açıınca, ayın 11'inci perşenbe günü vezirler, ulema ve şeyh efendiler, defterdârlar, padişah tarafindan temel atma törenine çağrıldılar.Duadan sonra ilk harç kondu ve sıkı bir çalışma ile bina alt ay içinde tamamlandı.Bu arada Seferli Koğuşu dar ve çirkin bir bina olduğu için o da yıktrılarak yerine ferah ve büyük bir bina yaptırıldı. Yukarıda anılan somaki direklerden 9'u gerektiği şekilde bu koğuşun saçağı altına yerleştirildi". ${ }^{22}$

Yukarıdaki kaynaklardan Râşid Tarihi'nde temel atma töreninin 1131 yılı Rebi'ü'l-âhir ayında olduğu kaydedilmekle birlikte gün kısmı boş bırakılmıştır. ${ }^{13}$ Buna karşılık Fındıklılı Mehmed Ağa, söz konusu tarihi 1131 yılı olayları bahsinde Rebi'ü'l-âhir ayının onbirinci Perşembe günü olarak açık biçimde göstermiştir. ${ }^{14}$ Buna göre yapının temel atma töreni H.11 Rebiü'l-âhir 1131 / M.3 Mart 1719 günü gerçekleşmiştir. Dönemin canlı şâhitleri olan Râşid Mehmed Efendi ve Silahdar Fındıklılı Mehmed Ağa'nın eserlerinde yapının

10 Kütüphanenin kuruluş nedeni Sultan III.Ahmet'in vakfiyesinde de benzer gerekçelerle ifade edilmiştir. Bkz. İsmail E.Erünsal, Osmanlı Vakıf Kütüphaneleri, Atatürk Kültür Merkezi Yayını, 2.Baskı,Ankara 1991, s.77.

11 Raşit Mehmet Efendi,age,C.II,s.1150.

12 Silahdar Fındıklılı Mehmet Ağa, age,C.II,s.384-385.

13 Râşid Mehmet Efendi, age,C.II,s.1150.

14 Silahdar Fındıklıı Mehmet Ağa, age,C.II, s.385. 
temel atma ve inşa tarihi başlangıcı kaydedilmiş olmasına rağmen, günümüz araştırmacılarından kimileri inşaat başlangıcı olarak farklı bir ayı göstermiş; bazılarında ise H.1131 tarihi verilmekle birlikte, bunun milâdî karşılığı olarak bazen 1718, bazen de 1719 yılı gösterilmiştir. Örneğin İsmail Erünsal, Topkapı Sarayı arşivinden kaynaklara dayanarak yapının temelinin 27 Rebiü'l-evvel 1131/ Ocak 1719 yılında atıldı̆̆ını belirtmektedir. ${ }^{15}$ Onun verdiği bu tarih Semavî Eyice tarafindan da kullanılmıştır. ${ }^{16}$

Sedat Hakkı Eldem, Şükrü Yenal, Metin Sözen ve ilber Ortaylı gibi kimi araştırmacılar ise miladî karşılık olarak 1718 tarihini tercih etmişlerdir. ${ }^{17}$ Fındıklılı Tarihinde yapının altı ayda tamamlandığı kaydedildiğine göre; yapım faaliyetinin yaklaşık olarak Şevval ayının onu veya onbiri civarında, yâni 1719 yılı Ağustos ayının sonlarına doğru bitmiş olması gerekir. Fakat Râşid Tarihinde bu hususa bir fasıl ayrılarak kütüphane inşasının tamamlanması vesilesiyle düzenlenen tören ve burada verilen ilk dersin H.10 Muharrem 1132 / M.23 Kasım 1719 günü yapıldığı anlatıldığına göre; binanın tamamlanması biraz daha uzun sürmüş olmalıdır. ${ }^{18}$ Bu açılış tarihinin Sadreddinzâde Telhisî Mustafa Efendi'nin Cerîdesinde de aynı biçimde kaydedilmiş olması 10 Muharrem 1132 tarihi konusunda şüpheye yer bırakmamaktadır. ${ }^{19}$ Muhasebe kayıtlarına göre kütüphane 19.570 kuruşa

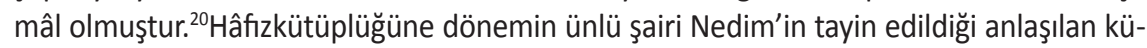
tüphanenin vakfiyesinde; yapılış sebebinden başka kitapların nereden temin edildikleri, kütüphane defteri, sadece pazartesi ve Perşembe günleri açık olacağı, saray dışına hiçbir şekilde kitap çıkarılamayacağı, burada ders verecek kişiler, kitaplık uzmanları, kapıcı, hademe, kurşuncu, tamirci ve diğer görevliler ile ücretleri gibi hususlar kayıt altına alınmıştır. ${ }^{21}$

Kütüphanenin inşa tarihi ve bânisini sunan en önemli belge, kapının üzerindeki kitâbedir. Taçkapı kavsarasının üstündeki yatay dikdörtgen mermer levha üzerindeki kartuşlara yazılmış oniki satırlık Arapça kitâbe; Sultan Ahmet'in, içinde kitapların toplanacağı bu binayı ilim öğrenmeyi özendirmek ve sevap kazanmak için kendi parasıyla yaptırdığını anlatmakta ve H.1131/ M.1719 tarihini vermektedir. Revağa bakan küçük çeşmenin alınlığındaki tek satırlık Arapça kitâbe de ebced hesabıyla tarih içerir. ${ }^{22}$ Aynı şekilde revak cephesine Kütüphanenin yaslanmış durumdaki diğer çeşmenin Türkçe kitâbesi hem ebced hesabıyla hem de rakamla H.1131/M.1719 tarihini sunar.

Ne kütüphane kitâbesinde ne de çeşmelerin kitâbelerinde mimar adı geçmez. Buna karşılık birçok yayında şehremini Beşir Ağa'nın binanın yapıcısı olduğu kaydedilmiştir. ${ }^{23}$ Goodwin, L.A. Mayer ve Doğan Kuban’a dayanarak onu “Mimar Beşir Ağa” olarak zikre-

15 İsmail E.Erünsal, age, s.79.

16 Semavi Eyice, "Ahmet III Kütüphanesi",Dünden Bugüne İstanbul Ansiklopedisi, C.1, İstanbul 1993, s.115.

17 Sedat Hakkı Eldem, Köşkler ve Kasırlar, II, s.195, Şükrü Yenal, "Topkapı Sarayı Müzesi Enderun Kitaplığı (Ahmet III. Kitaplığı)", Güzel Sanatlar , S.6, 1949, s.86-87; Metin Sözen, Topkapı, Hürriyet Gazetecilik ve Matbaacılık A.Ş., İstanbul 1998, s.91; İlber Ortaylı, Mekanlar ve Olaylarıyla Topkapı Sarayı, Bank Asya Kültür Hizmetleri, İstanbul 2009, s.115.

18 RâşidMehmet Efendi, age,C.II,s.1170.

19 İsmail E.Erünsal, age, s.79.

20 İsmail E.Erünsal, age, s.79.

21 Enver Ziya Karal, “Ahmet III”, İslam Ansiklopedisi,C.1, 2.Baskı, Eskişehir 1997, s.167; Şükrü Yenal, agm, s.88-89.

22 Şükrü Yenal, agm, s.86-87; Necdet Sakaoğlu, Tarihi, Mekanları, Kitâbeleri ve Anıları ile Saray-ı Hümayun: Topkapı Sarayı, Denizbank Yayını, İstanbul 2002, s.201-202.

23 Bkz.; Reşat Ekrem Koçu, Topkapu Sarayı, İstanbul 1960, s.74; Oktay Aslanapa, Osmanlı Mimarisi, İnkılâp Kitâbevi, İstanbul 1986, s.374. 
der. Goodwin, bu kişinin aynı zamanda Damat İbrahim Paşa Darülhadisi'ni de inşa eden mimar olduğunu vurgular. ${ }^{24}$ Şükrü Yenal bu ismi "şehremini Bekir Ağa" olarak kaydetmiştir. ${ }^{25}$ Kütüphaneye ait 1719 tarihli bir kayıt defterinde; III. Ahmet'in kitaplarını kütüphaneye vakfettiği ve hayır duayla anılmak için vakfedilen kitapların kendi mührüyle mühürlenmesini istediği yazılıdır. ${ }^{26}$

Kütüphanenin, ilk inşasından M.1856 yılındaki Enderûn yangınına kadar önemli bir müdahaleye uğramadığı sanılmaktadır. Bir asrı aşan bu sürede yapının durumuyla ilgili olarak; Levnî'nin minyatüründeki tasvir (Res.1) ile Miss Pardoe'nun 1836 yılı İstanbul izlenimlerini tasvir eden W.H. Bartlett'in gravürü (Res.2) ve 1852 yılında kütüphaneyi ziyaret eden Teophile Gautier'nin izlenimlerinden bilgi sahibi olabiliyoruz.

Gautier'ye göre; kütüphaneye ince işlenmiş mermer trabzanlı merdivenden çıkılarak ulaşılmaktadır. Kitaplığın içinde meşe ağacından raflarda yüzleri izleyiciye dönük Arap harfleriyle yazma kitaplar dizili bulunmaktadır. ${ }^{27}$ Bunlardan Levni minyatürleri ile Bartlett'in gravüründeki tasvirlerinde, kütüphanenin şimdiki görünümüne göre en çarpıcı farklılık revak ile merdivenin konumlarıdır. Levni'nin minyatürlerinde yapının revak ve arkadaki örtü sisteminde gerçekle ilgisi olmayan unsurlar görülmekle birlikte merdivenin revakla ilişkisinin doğru gösterildiği Bartlett'in gravüründen anlaşılabilmektedir. Buna göre, ilk yapıdaki merdivenler şimdiki gibi revakın yan kenarlarına değil; revakın ön cephesine bitişiktiler. İki kollu tek sahanlıklı merdivenden revakın orta kemeri açıklığına ulaşılıyordu. Merdiven başlarında mermerden kemerli birer tâk bulunuyordu. Merdivenin mermerden korkulukları vardı. Çeşme ise merdivenin kuzeydoğu cephesine bitişikti. Yapının bu hâlini tanımlayan bir başka belge ise S.H. Eldem'in yayınladığı 1840 tarihli suluboya tablodur. ${ }^{28} \mathrm{~S}$. H. Eldem bu verilere göre yapının restitüsyonunu yapmıştır. (Şek.2,3) Gautier'nin tasviri ise, ahşap kitaplığın (hazine-i kütüp) 18. yüzyılın kimi kütüphanelerinde olduğu gibi sofanın ortasında yer aldığı kanaatini uyandırmaktadır. Yapının inşa edildiği 1719 yılına ait masraf defterindeki kayda göre kütüphane kısmının alt pencereleri ahşaptan on bölmeli ve iki kanatlı olmalılar.

Kütüphanenin tarihi içinde en kayda değer müdahaleler 1856 yılındaki Enderun yangınından sonra yapılmış gibi görünüyor. Yapının cephesine sınırlı ölçüde zararı dokunduğunu sandığımız yangından sonra Enderun'da girişilen onarım faaliyetleri kapsamında giriş cephesine müdahale edilerek merdiven ve çeşmelerin konumlarının değiştirildiği anlaşııyor. Bu husus, özgün devreye ait görsel kaynaklar ile H.1308/M.1890 tarihli Topkapı Sarayı planı ve yangından sonraki yıllara ait en eski fotoğrafların mukayesesinden rahatılıkla anlaşılabilmektedir. ${ }^{29} \mathrm{Bu}$ dönemde geriye çekilerek revakın yan kenarlarına ve bina cephesine bitiştirilen merdivenlerin başındaki taklar kaldırılmış ve özgün merdiven korkulukları değiştirilerek pik korkuluklar konulmuştur. Necdet Sakaoğlu, Pencere aralarındaki gömme dolapların gümüş tel kafesli kapakların 19. yüzyılda yenilendiğini ileri sürer. ${ }^{30}$ Yazarın bu bilgisinin hangi kaynağa dayandığı belli değildir. Fakat diğer yazarların çalışmalarına ba-

24 Godfrey Goodwin, Osmanlı Mimarlığı Tarihi,Çev: Müfit Günay,Kabalcı Yayınevi, İstanbul 2012, s.470.

25 Şükrü Yenal, agm, s.87.

26 ìlber Ortaylı, age, s.115.

27 Theophile Gautier, Constantinopole, Paris 1891, s. 284-285;Gül İrepoğlu, age., s.23.

28 Bkz.; S. H. Eldem - F. Akozan, Topkapı Sarayı, Lev.183.

29 Bkz.; Sedat Hakkı Eldem - FeridunAkozan, Topkapı Sarayı, Lev.65-66.

30 Necdet Sakaoğlu, age, s.200. 
kılınca, Sakaoğlu'nun önceki yayınlardaki bazı ifadeleri yanlış anlamış olabileceği akla geliyor. Semavi Eyice de şimdiki ahşap dolapların 19.yüzyıl işi olduklarını ve kütüphanenin süsleme zenginliğine ve üslubuna ters düştüklerini vurgulayarak; bunların özgün hâliyle Ayasofya kütüphanesindeki dolaplar gibi, nakışlarla bezenmiş, tel kafesli olabileceklerini dile getirir. ${ }^{31}$ Şayet gömme dolap nişleri Enderun yangınından sonra yapılmış ise, söz konusu kafeslerin yüzyılın sonlarına doğru yenilenmiş olması düşünülebilir. 20 yüzyıl başlarına ait bir fotoğraf revak kemerlerinin arasına câmekân eklendiğini gösteriyor. 1902 yılında basılan Max Fruchtermann'ın bu kartpostalında câmekânın dışında çeşmenin yan nişlerindeki yalakların şimdikinden farklı tipte ve altlarında mermer sütunceler bulunduğu görülmektedir. (Res.3) Enderun yangınından sonraki onarım sırasında yapının süslemelerine müdahale edildiğine dair kayda değer bir kanıt veya kayıt bilinmiyor. Buna karşıık yapının ilk inşa aşamasına ait çini gruplarından farklı üç adet çini levha bu onarım sırasında kullanılmış olabilirler. Bunlardan özellikle ithal gibi görünen iki parçanın 19.yüzyıla uygun üslupları bu hipotezimizi desteklemektedir. İçeride tonoz ve kubbe yüzeylerini kaplayan alçı üzerine kalem işlerine de 1856 sonrası onarımında dokunulmadığını sanıyoruz. Osmanlı döneminin sonlarına doğru Muhafaza-i Âsâr-ı Atîka Encümeni Dâimisi'nin 10 Ekim 1915 tarihli raporunda ${ }^{32}$ sarayın yanlış müdahalelerle zarar gören veya yanlış onarımlarla asli hâlinden uzaklaşan kısımları sayılırken Enderun kütüphanesine değinilmemesi; 1856 yangınından sonra yapılan onarım ve düzenlemenin dışında 20. yüzyıl başlarına kadar yapıda dikkate değecek bir onarımın yapılmadığı kanaatini uyandırıyor.

Bu evre cumhuriyetin kuruluşundan günümüze kadar olan süreci kapsar. 1939-44 yılları arasındaki onarım, 1970 onarımları ve 1999 konservasyon ve restorasyonu bu aşama içinde yer alırlar. İlban Öz'ün Topkapı Sarayı'nda 1924 - 1980 yılları arasında yapılan onarımları özetleyen makalesinden 1924 yılından 1970 yılına gelinceye değin kütüphanede önemli sayılabilecek onarımların yapılmadığı anlamı çıkmaktadır. ${ }^{33}$

Fakat farklı tarihlere ait fotoğraflar özellikle revak camekanlarına bu süreler içerisinde müdahalelerin yapıldığını kanıtlıyor. 1902 tarihli karpostalda büyük kare çerçeveli şeffaf camlara sahip durumdaki revak camekanları Tahsin Öz'ün 1939-1944 yılları onarımlarını anlattı̆ı makalesinde yıkılmış selviye rağmen aynı görünmektedir. Yazarın 1941 yılında yayınladığı fotoğrafta değişikliğe uğramış olduğu tespit edilmektedir.Fotoğrafa göre camekanın pencereleri daha küçük boyutlu demir çerçeveli olarak yenilenirken bunların arkası çapraz çıtalı kafesle kaplanmıştır. ${ }^{34}$ Bu fotoğrafta çeşmenin yan nişlerinin önünde şimdiki mukarnaslı yalakların bulunduğu, fakat onları destekleyen sütuncelerin mevcut olmadıkları görülmektedir. ${ }^{35}$ Topkapı Sarayı Müzesi arşivindeki (TSMA) 1920 yılına tarihlenen fotoğrafta da şimdiki yalakların görülmesi; 1902 - 1920 yılları arasında bu yalakların yerleştirildiğini gösteriyor. (Res.4) Söz konusu yalakların işçilik bakımından çeşmeyle uyumlu görünüşleri bunların özgün olabileceklerini akla getirmektedir. Yine TSMA arşivindeki iç mekan fotoğrafları 1939-1944 yılları arasında yapının içinde tadilat yapıldığını, muhtemelen bazı çini kaplamaların konservasyonlarının gerçekleştiğini anlatıyor. Bu

31 Semavi Eyice, agm, s.116.

32 Sedat Hakkı Eldem - FeridunAkozan, Topkapı Sarayı, s.100-102.

33 İlban Öz, "Topkapı Sarayı Onarımları", Sanat, S:7, 1982, s.65-76.

34 Bkz.; Tahsin Öz, "La BibliothéqueduPalais de Topkapı", La TurquieKemaliste, No.45, 1941, p.7-11; Tahsin Öz, “Topkapı Sarayı Müzesi Onarımları”, Güzel Sanatlar, S:6, 1949, s.6-74, res.132.

35 Tahsin Öz, "La BibliothéqueduPalais de Topkapı”, p.7. 
süre zarfinda bir kar firtınasıyla yıkılarak revaka çarpan selvi ağacının yapıya çok ciddi bir hasar vermediği, sadece örtü sistemindeki kurşun kaplamaların onarıldığı ifade edilmektedir. ${ }^{36}$ Tahsin Öz'ün yayınladığı makalelerdeki fotoğrafların kronolojisine bakılırsa; kar firtınasının sebep olduğu cephe hasarı 1939-1940 yılları arasında vuku' bulmuş ve kubbe kurşunlarının tamiri, revak camekanlarının küçük çerçeve ve çapraz kafeslerle yenilenmesi ile iç tâdilat da bu olayın akabinde, fakat 1941 yılından önce yapılmış olmalıdır. Söz konusu câmekan sonradan kaldırılmıştır.

Yapıya yönelik en son restorasyon ve konservasyon çalışmaları Kültür ve Turizm Bakanlığı tarafindan 2014-2018 yılları arasında yapılmıştır. Bu çalışmalarda özellikle yapının tonoz ve kubbelerinin iç yüzlerini kaplayan alçı bezeme elden geçirilmiştir.

\section{KÜTÜPHANENIN MIMARîSI :}

16. yüzyıldan kalma Havuzlu Köşk'ün yerine inşa edilen III. Ahmet Kütüphanesi bir bodrum kat ve bunun üzerine oturan asıl kütüphane bölümünden oluşur. (Res.1) Giriş kanadında üç bölmeli bir revak ve revakın cephesine bitişik bir çeşme ve revakın orta kısmına dönük küçük boyutlu ikinci bir çeşme bulunur. (Şek.4,5) Revak ve merdivenlerle birlikte 15,60 x 18,10 m. lik bir alan üzerine oturan yapı, çok sayıda pencereyle çözülmüş cepheleri, revakı ve kurşun kaplamalı örtü sistemiyle türünün en anıtsal örneklerinden birisidir. Binanın ana kütlesi 9,20×18,10 m.lik enlemesine doğrultuda dikdörtgen prizması biçimindedir. Bu kütleyi arka cephede dar bir çıkınt ile ön tarafta revak kütlesi tamamlar. Bu kısımlarla birlikte üstten $(\mathrm{t}$ ) biçiminde haçvari bir görünüm ortaya çıkar. Buna karşılık iç mekan düzeni ters $(T)$ biçiminde bir izdüşüm gösterir.

Kütüphanenin bodrum kat duvarlarında taş ve tuğlaların münavebeli dizildiği almaşık teknik uygulanmıştır. Yapının kütüphane katı duvarları kaba yonu taşlar kullanılarak yığma duvar tekniğinde inşa edilmiştir. Tüm duvarlar dıştan mermerle kaplanmıştir. İçerdeki kemerler ve alt pencerelerin söve ve lentoları da mermer kaplamadır. Sütunlar ve başlıklar mermerdendir. Aynı şekilde çeşmelerde de mermer kullanılmıştı. Binanın 1719 tarihli inşa defterindeki kayıtlara göre; kullanılan taşların bir kısmı Boğaziçi’nden getirilmiştir. Bir kısım taşın buradaki eski Havuzlu Köşk'ün yıkılmasıyla elde edildiği tahmin edilebilir. Aynı şekilde, cepheleri kaplayan mermerlerin bir bölümü yıktırılan Havuzlu Köşk'e ait olmalıdır. Fakat bir kısım mermerin Marmara adasından getirildiği kayıtlara geçmiştir. Ahmet Refik'in yayınladığı 1719 yılı Mayıs ayı başlarına (evâsıt- cemâziye'l-âhir 1131) ait olup Marmara nâibine ve subaşısına gönderilen bir buyrukta: "Hâlâ müceddeden binasına şuru' olunan kitâbhâne-i Hümâyûniçün iktiza iden pencere söğesi ve sair mermerler hâlâ şehir emini ağa tarafindan irsal olunan memhûr defter mûcibincetâyin olunan haseki marifetile bir gün ve bir saat evvel irsal olunan sefâyinevaz'u tahmil ve muaccelen irsal ve isal idüb bir vechile müsamaha ve tekâsül olunmayub ziyâdete kayyüd ve ihtimam eylemeleriyçün emr-i şerîf yazılmışdır" denilmektedir. ${ }^{37}$ Kütüphanenin zemini altıgen tuğlalarla kaplanmıştır. Bunların benzerleri sarayın başka bölümlerinde de görülebilmektedir. Dolayısıyla tuğla döşemeler özgün olmalıdır. Üst sıradaki pencerelerin sivri kemerlerinin tuğladan örülüp, dıştan mermer, içten sıva ile kaplandıkları sıva raspasının altından görülebilmiştir. İçerde kubbe eteği ile köşeler arasındaki düz tavanın

36 Fotoğraf için bkz.; Tahsin Öz, "Topkapı Sarayı Müzesi Onarımları”, Güzel Sanatlar, S:6, 1949, s.6-74, res.132.

37 Ahmet Refik, age, s.64. 
taşıyıcı unsurlarının demir gergiler olduğu sıva raspasının altından görülmüştür. İçerdeki kemerlerin arasında da demir gergiler kullanılmıştr. Kubbe ve tonozlar dıştan kurşunla kaplıdır. Bu kurşunların bir kısmının, buradaki Havuzlu köşkten alındığına dair kayıt vardır. Geriye kalan kurşun ihtiyacı ise Karabali Kasrı, Fazlı Paşa Sarayı (eski Ibrahim Paşa Sarayı) ve İstavroz kasrından karşılanmıştır.38 Ahşap malzeme sadece bodrum zeminindeki hatıllarda, kapı ve pencere kanatları ile dolaplarda kullanılmıştır.

Plan açısından bodrum kat, güney bat kenardaki eyvan tarzı çıkıntiyla birlikte ters (T) biçimindeki şema içinde masif ayaklarla bölümlenmiştir. Bodrum, arka cephede (güneybat) alt, kuzeybatıda üç, revakın bulunduğu cephede bir ve güneydoğu cephede iki olmak üzere toplam oniki pencereden ışık alır. Pencereler dıştan düşey dikdörtgen çerçeveli olup, içten mazgal tarzında düzenlenmişlerdir. Güneydoğu cephenin doğu köşe yakınındaki küçük kapı ile bodruma girilir. Bodruma çok destekli bir görünüm kazandıran ayaklardan on tanesi mekanın dikdörtgen planlı ana hacminde sıralanır. Güneybat kanattaki eyvan biçimli çıkınt içinde ise bir adet ayak bulunur. Ana hacimdeki ayaklardan kuzeybat kanattaki iki destek, dikdörtgen biçiminde olup diğerlerinden farklı ve daha büyük tutulmuştur. Bu farklılık, muhtemelen burada mevcut olan havuzlu köşke ait duvar ve desteklerden -belli oranda da olsa- yeni inşa sırasında yararlanma çabasından kaynaklanmış olmalıdır. Bodrumda ayakların arasındaki açıklıklar beşik tonozlarla örtülmüştür. Ayakları birbirlerine bağlayan yuvarlak kemerler tonoz kavislerinin içine gömüldüklerinden, ayaklar arasında haç tonoza benzer bir örtü görüntüsü doğmuştur. İçerde ayak ve duvar yüzeylerinde görülen yazılar farklı dönemlere ait olup özel bir anlam taşımazlar. Birçok araştırmacıya göre bodrum kat, kütüphanenin rutubet almasını önlemek için düşünülmüştür.39 Bodrum katın cepheleri ile kütüphane kısmının cepheleri profilli silmeli bir kornişle birbirinden ayrilırlar.

Sedat Hakkı Eldem' in "üç çıkmalı, tek elemanlı ve haç şeklinde" ${ }^{40}$ bir köşke benzettiği kütüphanenin asıl bölümünün cepheleri iki kat hâlinde dizilen toplam kırk adet büyük pencere ile çözülmüştür. (Res.6,7) Bunlardan onalt tanesi arka cephe ve buradaki çıkmada yer alırken; yan cephelerde altş̧ar adet ve giriş cephesinde oniki adet pencere bulunur. Alt pencereler düşey dikdörtgen çerçeveli iken üst pencereler sivri kemer biçiminde düzenlenmişlerdir. Ön cephedeki üç bölmeli revakın sivri kemerleri dördü cepheye bitişik dördü müstakil olmak üzere toplam sekiz mermer sütuna biner. (Res.4) Revakın orta bölümü içten nervürlü kubbeyle örtülürken yan bölümlerde aynalı tonoz kullanılmıştr. Revakın yan kenarlarındaki merdivenler cepheye bitişik biçimde yükselirler. Bu merdivenlerin aslında revakın önünde iken sonradan buraya alındıkları anlaşılmaktadır. Kuzeydoğuya bakan giriş cephesindeki pencerelerden taçkapının iki yanındakiler revak içinde kalmaktadır. Revakın cephesine bitişik olan çeşmeler yer alır. Binanın cepheleri profilli saçak kornişiyle tamamlanır. Mekanları örten kubbe ve aynalı tonozlar dıştan kurşunla kaplanarak tıpkı camilerde olduğu gibi birer alemle taçlandırılmışlardır. Yapının sofasını örten kubbe, dıştan sekizgen kasnağa biner.

Revakın orta bölümünün sütunları arasına yerleştirilen yuvarlak kemerli kavsaranın altında, basık kemerli açıklığa sahip taçkapıdan geçilen kütüphane; ortada kare planlı

38 Sedat Hakkı Eldem, Köşkler ve Kasırlar, II, s.195.

39 Bkz.; Şükrü Yenal, agm, s.86; Sedat Hakkı Eldem, Köşkler ve Kasırlar,ll,s.199; Semavi Eyice, agm, s.115.

40 Sedat Hakkı Eldem, Köşkler ve Kasırlar, II, s.198. 
- kubbeli sofa ile buna üç yandan bağlanan eyvanlardan oluşur. Böylece aksiyal dört eyvanlı plan tipinin üç eyvanlı versiyonu olarak karşımıza çıkan kütüphanede eyvanların her biri dört mermer sütuna binen üçer kemerle ortadaki sofaya açılırlar. Kemer açıklıklarında üzengi hattının üzerine demir gergiler yerleştirilmiştir. (Res.8,9,10)

Eyvanların zemini sofa zemininden birer basamak yüksek tutulmuşlardır. Bu düzenleme eyvanların okuma mekanları olarak değerlendirildiklerini düşündürüyor. Bunlardan girişin karşısındaki eyvan, planda yapı kütlesinden çıkınt yapan ünite olup; bazı ayrıntlarıyla diğer iki eyvandan daha özenle ele alınmıştır. Diğer eyvanları sınırlayan sütunlara üçer sivri kemer binerken; girişin karşısındaki eyvanın sadece orta açıklığının üzerinde sivri kemer kullanılmış, yanlarda ise dar ve düz atkı biçiminde kemer tercih edilmiştir. Bu kısımda yandaki sütunların arasına şebekeli mermer korkuluklar konulmuştur. Söz konusu eyvanın arka duvarında alt pencerelerin üstündeki kartuşlardaki yazıların III. Ahmet'in kendi hatt olduğu kabul edilir. Bütün bu özellikleriyle söz konusu eyvanın sultana mahsus olarak tasarlandığı anlaşılmaktadır. Bu nedenle burayı "hünkâr eyvanı" olarak adlandırmak uygun görünmektedir. Hünkar eyvanı boyutunun küçüklügü̈yle de diğer eyvanlardan farklıdır. Sofanın iki yanına karşılıklı olarak yerleştirilen yan eyvanlardan kuzeybatı taraftaki diğerinden daha derin tutulmuştur. Hiçbir topoğrafik zorlama olmamasına rağmen yan eyvanlar arasındaki bu asimetrik durum; -bodrum katındaki kuzeybat taraftaki ayağın farklıı̆ında olduğu gibi- Havuzlu Köşk'e ait alt yapının yeni bina için kullanılmaya kalkılmasından kaynaklanmış olmalıdır.

Yapının içi dört cephedeki toplam kırk pencere ile işlevine uygun derecede ışık almaktadır. Pencerelerin iç biçimleri de dıştaki gibidir. Yâni alt pencereler düz lentolu, üst pencereler ise sivri kemer biçimlidir. Alt pencereler içten ikişer ahşap kanatla örtülürken; üst pencereler içlik ve dışlık düzeneğine sahiptirler. Bunların dıştan ahşap çerçeveli düz camlı dışlıkları varken; içte, ahşap kenar çerçevesi içinde alçı revzenli renkli ve şeffaf camlı içlik pencereleri vardır. Alt pencerelerin arasındaki ahşap çerçeveli nişler kitap dolabı işlevi görürler.

Ortadaki sofayı örten kubbeye geçişte tromp, pandantif gibi geleneksel elemanlar kullanılmamıştır. Bunların yerine, kubbe eteği ile köşeler arasına çapraz demirler atılarak düz tavan biçiminde bir çözüm sağlanmıştir. Eyvanlar aynalı tonozla örtülmüştür.

Yapıyla beraber tasarlandıkları anlaşılan iki çeşmeden meydana bakanı diğerinden daha büyüktür. İlk inşa edildiği dönemde, revakın önünde duran iki kollu - tek sahanlıklı merdivenin cephesine bitişik konumdaki bu çeşme; 19.yüzyıl ortalarındaki tamir sırasında yapılan değişiklikle revağa bitişik duruma getirilmiştir. Zarif bir mimariye sahip olan mermer çeşme tek cepheli olup; ortada mukarnas kavsaralı ana niş ile iki yanındaki, küçük sivri kemerli birer nişten oluşur. Ortadaki nişin önünde dilimli yarım daire biçiminde çeşme yalağı yer alır. Yan nişlerin yalakları ise çok zarif sütun başılılarına benzerler. Bunları alttan destekleyen sütunceler yok olmuştur. Çeşme, anıtsal bir alınlık ile tamamlanır. Şimdiki haliyle revakın orta kısmına dönük duran küçük çeşme; yekpare mermerden yuvarlak kemerli niş, bunun önünde yarım daire plan üzerine çok dilimli kenara sahip bir yalaktan meydana gelir. Nişteki üç musluktan ikisinin gözleri kapatılmıştı. Bu çeşmenin cephesi mukarnaslı bir frizden sonra nervürlü kubbeyi andıran bir alınlıkla sona erer. 


\section{YAPIDAKI BEZEMELERIN GENEL NITELIĞi:}

Yapıya mimari süsleme açısından bakıldığında dış cephelerdeki mermer işçiliği ile içerde mermer, çini, alçı ve alçıları kaplayan kalem işleri hemen göze çarpar. Bunların dışında ahşap giriş kapısı ile alt pencerelerin ahşap kanatlarındaki fildişi, bağa ve sedef kakmalı bezemeleri, üst sıra pencerelerinin içlik kısımlarındaki renkli camlar ve kubbeden sarkan kandil zarfı (fanus) da iç mekanın zengin görünümünü pekiştirirler. Fakat bu yazımızda sadece çini bezemeler ele alındığından diğerlerine değinilmeyecektir

\section{4. ÇINI BEZEME :}

Çini bezeme, içerdeki mermer yüzeyler ile pencere ve dolap nişlerinin dışında kalan tüm duvar yüzeylerini tavan eteğine kadar kaplamaktadır.

Bu dönemde Osmanlı çiniciliğinin gözde merkezi İznik eski ihtişamını yitirmiş durumdadır. İznik çiniciliğini eski güzel günlerine döndürmek için sarayın ve Damat İbrahim Paşa'nın çabaları yetersiz kalmıştı. ${ }^{41}$ Öyle ki; Kütüphanenin duvarlarında kullanılacak İznik çinisi imal ettirilemediği için İstanbul'daki muhtelif yapılardan sökülüp getirilen çiniler kullanılmak zorunda kalınmıştı. Buna dair arşiv belgelerinde bilgiler bulunmaktadır. Sedat Hakkı Eldem'in yapıya ait M.1719 tarihli inşa defterlerinden naklettiği bilgilere göre; İstavroz bahçesinden, Boğaziçinden, Kara Mustafa Paşa yalısından ve Kandilli bahçesinden çiniler getirtilmiştir. ${ }^{42}$ Oktay Aslanapa, Ara Altun ve B.Demirsar Arlı'ya göre yapının iç duvarlarında Kara Mustafa Paşa Yalısı'ndan getirildiği bilinen 17. yüzyıl çinileri kullanılmıştı.43 İnşa defterinde kaydedilen İstavroz Bahçesi'nin, Boğaziçinin Anadolu yakasında Beylerbeyi Sarayı'nın yayıldığı alanı kapsadığı ve daha önceden burada İstavroz kasrı (16.yy.ın ikinci yarısı) ve I. Ahmet'in Şevket-âbâd sarayının (17.yy. ilk çeyreği) bulunduğu biliniyor. Kandilli Bahçe denilen yerde ise IV. Murad’ın yaptırdığı Nev-âbâd Sarayı (17.yy. ikinci çeyreği) bulunuyordu. Bu saray $1718^{\prime}$ de Nevşehirli Damat İbrahim Paşa tarafindan tamir ettirildiğine göre; buradaki çinilerin bir kısmı söz konusu tamir sırasında alınmış olabilir. 17. yüzyıl devlet adamlarından olan Kara Mustafa Paşa'nın iki tane yalısı biliniyor. Bunlardan birisi Eyüp-Kâğıthâne'deydi. Sadrazam Nevşehirli Damat İbrahim Paşa 11 Nisan 1720 tarihinde bu yalıda Avusturya elçisine ziyafet vermiştir. ${ }^{44} \mathrm{Bu}$ bilgi, Kâğıthâne'deki yalının 1720 yılında, yâni kütüphane yapıldıktan sonra da ayakta olduğunu gösteriyor ve çinilerin bu yalıdan alınmadığını da ortaya koyuyor. Diğeri ise Emirgan'da olup; aslında buraya adını veren Emirgûne Yusuf Paşa'ya ait olan yapıdır. Yapı Yusuf Paşa'nın idamından sonra Kara Mustafa Paşa'ya geçmiştir. Sedat Hakkı Eldem de, kitabında bu noktayı vurgulamak için parantez içinde "aslında Emirgan Yusuf Paşa Yalısı" kaydını düşmüştür. ${ }^{45}$ Bize göre de kayıtta çini alındığı kaydedilen Kara Mustafa Paşa Yalısı Emirgan'daki yapı olmalıdır. Defterdeki Boğaziçi kaydı çok genel bir ifadedir. Çünkü boğa-

41 Bkz.; Önder Küçükerman, Sanayi ve Tasarım Yarışında Bir Imparatorluk iki Saray, Yapı Kredi Yayınları, İstanbul 2007, s.171-172.

42 Sedat Hakkı Eldem, Köşkler ve Kasırlar II, s.195. Eldem, söz konusu defteri 1718 tarihli olarak göstermiştir. Daha önce de söylediğimiz gibi bu farklılık hicri tarihin miladiye çevrilmesi sırasındaki bir hatadan kaynaklansa gerektir.

43 Oktay Aslanapa, Osmanlı Mimarisi, s.374; Belgin Demirsar Arlı- Ara Altun, Anadolu Toprağının Hazinesi Çini: Osmanlı Dönemi, Kale Grubu Kültür Yayınları, İstanbul 2008, s.135.

44 Bkz.; Murat Yıldız, "Türk Sivil Mimarisinin en Eski Yapılarından Amcazâde Hüseyin Paşa Yalısının Tarihî Serüveni", Türkiyat Mecmuası, C.21, İstanbul 2011, s.399, 412.

45 Sedat Hakkı Eldem, Köşkler ve Kasırlar,II, s.195. 
zın hem Anadolu hem de Rumeli tarafinda 16. ve 17. yüzyıldan birçok saray, köşk ve yalı vardır. Yukarıda sayılan bazı köşklere ek olarak Rumeli yakasında, şimdiki Dolmabahçe sarayının yerinde bulunan Beşiktaş Sarayı'ndaki Çinili Köşk de (M.1679-80) hatırlanabilir. Bu köşk 19. yüzyılın ortalarında Dolmabahçe sarayı inşası sırasında yıktııımıştır. ${ }^{46}$

Yapıdaki çiniler kompozisyon bakımından altı gruba ayrılırlar. Ayrıca tarihini bilmediğimiz onarımlar sırasında yapının içine konmuş bir kaç parça, ayrı bir grup oluştururlar. Söz konusu gruplar ve özellikleri aşağıda ifade edilmişlerdir:

\subsection{Girişin İç Cephesi ve Hünkar Eyvanındaki Çiniler:}

Bu kısımlardaki çinilerde beyaz zemin üzerine koyu mavi, türkuaz ve kırmızı renklerin kullanıldığı, sekiz ve dört kollu yıldızlarla birbirine bağlanmış hatayî ve rûmîlerden oluşan kompozisyon ulama teşkil edecek düzende tekrarlanmaktadır. (Res.11) Bu çiniler dört taraftan koyu mavi zemin üzerine beyaz, türkuaz ve kırmızı renklerin kullanıldığı çintemanili bir bordürle kuşatılmışlardır. Hünkar eyvanının yan cephelerinde kaplamaların üst kenarı boyunca çintemanili bordürden sonra beyaz zemin üzerine yeşil renkte rûmî motiflerinin tekrarlandığı ikinci bir bordür görülmektedir. (Res12) Burada karşılaşılan çintemanili bordürün neredeyse aynısı sayılabilecek parçalara, İznik Eşrefi Rûmî minaresine 1619 - 1629 yılları arasındaki tamir sırasında eklenmiş çiniler arasında rastlanmaktadır. ${ }^{47}$ Girişte kapı açıklığının iç duvar yüzeylerini kaplayan büyük çini panolar açıklı̆ın iki yanına simetrik yerleştirilmişlerdir. Kapı kanatları açıldığında onların arkasında kalan bu panolar dört taraftan bordürle kuşatılmış, dilimli ikiz kemerle sona ererler. Panoları teşkil eden kare çini levhalara beyaz zemin üzerine mavi ve türkuaz ile hatayi ve penç motifli kıvrık dallar işlenmiştir. Hatayi ve pençlerden çıkan yapraklar artk dişli hançer yaprağı biçiminde düzenlenmemişlerdir. Bordürde (C) biçiminde iç bükey hatla birbirlerine bağlanan tırtıllı palmetler tekrarlanmaktadır. (Res.13) Dilimli kemerlerin köşeliklerinde kanatlı rûmî ve palmetlerden oluşan girift kompozisyon yer alır. Buradaki çiniler kompozisyonlarıyla Eminönü'ndeki Yeni Cami'nin (M.1663) hünkâr mahfilindeki çinilerle benzerlik gösterirler.

\subsection{Kuzeybatı Eyvanındaki Çiniler:}

Buradaki çinilerde; merkezdeki rozetin çevresini dört yönden kuşatan helezonik dalların ucundaki dişli yapraklar, ulama kompozisyonunun ana şemasını teşkil eder. (Res.14) Dişli yaprakların içinde bahar çiçekleri yer alır. Kompozisyon şeffaf sıraltında beyaz zemin üzerine koyu mavi, yeşil ve kırmızı renklerle işlenmiştir. Bu çinilerin neredeyse aynısı sayılabilecek örnekler İstanbul Ayasofya Camii'nde apsis duvarının güneyindeki 1643 tarihli çini panoda dikkati çekmektedir.48 Kuzeybat eyvanındaki bordürlerde Hünkar eyvanındaki çintemanili çinilerin yanı sıra; ortadaki hatayînin iki tarafina işlenmiş ikişer dişli yaprak ve iki uca yerleşen şemse motifinin tekrarlandığı bordür çinileri de kullanımıştr. Bu tarz bordür çinilerinin benzerlerine Antalya Murat Paşa Camii (1570) pencere alınlıklarında da rastlıyoruz. Fakat asıl benzer bordür çinisi İznik Eşrefi Rumî minaresinde (1619-1629 onarımı) göze çarpar. Bu eyvandaki çini kaplamalar tavan eteği boyunca uzanan dişli yapraklı palmet motiflerinin tekrarlandığı bir bordürle sona erer. Ayasofya

46 Sedat Hakkı Eldem, Köşkler ve Kasırlar, II, s.125.

47 Bkz.; Belgin Demirsar Arlı - Ara Altun, age, s.293.

48 Bkz.; Belgin Demirsar Arlı - Ara Altun, age, s.271. 
Camii'nde yukarıda söz ettiğimiz çini panonun üst kenarında da benzer motifli bir bordür çinisi yer alır.

\subsection{Güneydoğu Eyvanındaki Çiniler:}

Bu mekandaki çini kaplamalarda ana kompozisyon; merkezde ters palmeti andıracak şekle düzenlenmiş simetrik iki kanatlı rûmînin kuşattığı bahar dalı motifi ve bunları çevreleyen sekiz adet hatayî motifinden oluşmaktadır. (Res.15) Beyaz zemin üzerine işlenen motiflerden kanatlı rûmîler kırmızı renktedir. Diğerlerinde mavi ağılıklı tonlar kullanılmıştır. Bu ulama kompozisyonların kuşatan bordürlerde iki farklı çini grubu kullanılmıştır. Bordür çinilerinden birisinde mavi zemin üzerine çin bulutu ve hatayî motifleri tekrarlanmaktadır. Diğerinde ise ortadaki büyük hatayînin iki yanında simetrik küçük hatayî motifleri bulunmaktadır. Bu eyvandaki çini kaplamaları en üstten sınırlayan bordürde beyaz zemin üzerine büyük ve küçük boyutlu dişli palmetler münavebeli olarak sıralanmışlardır.

\subsection{Güneydoğu Eyvanının Güney Köşesindeki Çiniler:}

Güneydoğu eyvanının güney köşesini düşey konumda kaplayan çiniler sayıca az olmakla birlikte diğerlerinden farklıık gösterirler. (Res.16) Bu çini levhalarda; içinde bahar dalı olan dişli yapraklarla kuşatılmış şemseli kompozisyon görülmektedir. Yeşil, kırmızı ve beyaz renkler hakimdir. 17 yüzyıl ilk yarısından Sultan Ahmet Camii'nin mahfilinde bu çinilere yakın kompozisyonlar görülmektedir.

\subsection{Eyvanların Süpürgelik Seviyesindeki Çiniler:}

Güneydoğu eyvanının ve kuzeybat eyvanının süpürgelik seviyesinde, mekanların üç kenarını dolaşan çiniler diğerlerinden değişik kompozisyonlarıyla ayrı bir grup oluştururlar. Bu grup çini levhalarda, beyaz zemin üzerine sekiz kollu yıldız çevresinde münavebeli biçimde sıralanmış dört şemse ve dört hatayî motifi görülmektedir. Hatayîler, levhanın merkezindeki yıldıza çapraz konumda yerleşen şemselerin arasına işlenmiştir. Motifler ince kıvrık dallarla birbirlerine bağlanmıştır. Yıldızda ve şemselerde yeşil renk hakimken hatayîlerde kırmızı ve mavi renk kullanılmıştır. (Res.17)

\subsection{Pencere İç Duvarlarındaki Çiniler:}

Pencerelerin iç yan duvarlarını kaplayan çinilerde beyaz zemin üzerine mavi tonlarının hakim olduğu, türkuaz ve yeşilin de belli oranda kullanıldığı görülmektedir. (Res.18) Kare levhaların merkezindeki iri hatayînin iki yanına simetrik düzende kıvrık dallı, büyük ve küçük dişli yapraklar, üst tarafta simetrik stilize lale motifleri yerleştirilmiştir. Bunları kuşatan bordürlerde ise (S) biçiminde zencirek oluşturan kıvrık dala bağlı hatayî, rozet ve penç motifleri tekrarlanmaktadır. Pencere içlerindeki çiniler kalite bakımından diğerleri kadar başarılı sayılmazlar. Bu gruptaki çinilerde zemin diğerleri gibi berrak beyazlıkta değildir. Sırın altında boyalar yer yer dağılmıştır. Bu da işçilikte bir bozulmaya işaret eder. Yıldız Demiriz, 17. yüzyıl çinilerinin teknik ve renk kalitelerindeki gerilemeye dikkat çekmiştir. ${ }^{49}$ Fakat bu gerilemeyi 17. yüzyılın tümü için ileri sürmek yanıltıcı olabilir. Çünkü 17. yüzyılın yaklaşık olarak ilk otuz yılı boyunca İznik çinilerinin klasik kalitesi korunmuş gö-

49 Yıldız Demiriz, "17. Yüzyıl Çinilerinde Değişen Desen Anlayışı", 17. Yüzyıl Osmanlı Kültür ve Sanatı, Sempozyum Bildirileri (19-20 Mart 1998), İstanbul 1998, s.77. 
rünüyor. Yukarıda vurgulanan gerileme ise özellikle 17. yüzyılın ortalarından itibaren söz konusu olabilir. Bu açıdan, kütüphanenin pencere içlerindeki çinilerin 17.yüzyılın ikinci yarısına ait bir yapıdan getirilmiş olabilecekleri ileri sürülebilir. Buradaki renk skalası ve kompozisyonların, 1663 yılında tamamlanan İstanbul Yeni Cami çinilerini çağrıştırdıklarını söyleyebiliriz.

\subsection{Onarımlar Sırasında Konulmuş Olabilecek Çiniler:}

Kütüphanenin çinileri arasındaki üç adet levha; teknik ve üslûp açısından farklılıklarından ziyade, sayıca azlıkları nedeniyle ilk inşa aşamasına ait olamazlar. Bunlar güneydoğu eyvanının kuzeydoğu duvarındaki pencere içine, yukarıda bahsettiğimiz çinilerin arasına yerleştirilmişlerdir. Bu çinilerin yapıya niçin ve ne zaman getirildikleri bilinmese de; bunların bir onarım sırasında eksik parçaların yerine konuldukları söylenebilir. Söz konusu üç örnekten birisi renkli sır tekniğinde bordür çinisi olup, kronolojik bakımdan 15. yüzyılın ikinci yarısı veya 16. yüzyılın ilk yarısına tarihlenebilir. (Res.19) Sarı, mavi, türkuaz, yeşil ve beyaz rengin kullanıldığı çinide rûmî ve palmet motifli kompozisyon egemendir. Bu parçanın Topkapı Sarayının zamanla yıkılıp ortadan kaldırılmış bir biriminden arta kalan parça olması muhtemeldir. Diğer iki çini, üslûp açısından ithal çinileri akla getiriyorlar. Bunlardan birisinde beyaz zemin üzerine mavi ve sarı tonlarında çiçekler, kırık hatlı çerçevelerin içine yerleştirilmiştir. (Res.20) Diğer parçada ise beyaz zemin üzerine sarı, yeşil, mavi renklerle dilimli şerit ve Barok tarzda bitkisel kompozisyon işlenmiştir. (Res.21) Topkapı sarayında Barok desenli bu çininin aynısı olan iki levha daha bulunmaktadır. Bunlar haremde III. Murad dairesinin (Has Oda) ocağının iki yanındaki dar nişlerin zeminlerine konulmuşlardır. Bu ithal işi gibi görünen çinilerin aynıları sarayın Ak Ağalar koğuşundaki Kapı Ağası Hamamı duvarlarında da görülmektedir. Kütüphanedeki bu iki parça ithal olabilecekleri gibi, onlara öykünen Kütahya işleri de olabilirler.

\section{DEĞERLENDIRME VE SONUÇ:}

Türk kültür tarihinde kitap yazarlığı, kitap koleksiyonu ve kütüphanecilik geleneğinin Selçuklu çağından itibaren oluşmaya başladığı söylenebilir. Selçuklu ve onu izleyen beylikler devirlerinde kitapların muhafaza edildiği yerlerin daha çok medrese türü yapılar içinde bir mekan ya da hücreden ibaret olduğu anlaşılıyor. Zaman zaman vakıf kayıtlarında göze çarpan kitaplar ve kitaplık bilgileri bu sınırlı durumu gösterir. Osmanlıların erken dönemlerinde de benzer bir durumdan söz edilebilir. Klasik Osmanlı döneminde külliyelerin içindeki ve saray içindeki kitaplıkların müstakil binalar olmadıkları tespit edilebiliyor. Osmanlı devrinde ilk bağımsız kütüphane binaları 17. yüzyılda ortaya çıkmış olup; bu dönemde en dikkat çeken örnek Köprülü kütüphanesidir. Fakat kütüphanecilik ve kütüphane mimarisi konusundaki asıl gelişmeler III. Ahmet devriyle başlar ve onu izleyen 18. yüzyılın üçüncü çeyreği ve sonrasında müstakil kütüphane yapıları yaygınlaşır ve kütüphanecilik anlam kazanır.

III. Ahmet Kütüphanesi'nin (M.1719) burada mevcut Havuzlu Köşk'ün yerine inşa edildiği dönemin kaynaklarında anlatılmaktadır. Kütüphanenin bodrum kat planı, kütüphane katında yan eyvanların derinlik bakımından asimetrik ölçüleri ve bodrum katın malzeme ve duvar tekniği ile üst kat arasındaki farklılık; yeni binanın inşası sırasında belli bir oranda Havuzlu köşkün duvarlarından yararlanıldığını düşündürmektedir. Goodwin de, özellikle eyvanların boyutları ve revak ile pencere ilişkilerindeki asimetrik durumu Havuzlu 
Köşk'ün temellerinin yeniden kullanılmasına ve Beşir Ağa'nın uygun plan yapamamasına bağlamaktadır.50

Bazı araştırmalarda III.Ahmet Kütüphanesi'nin, mimari bakımdan 17. yüzyıldan Köprülü Kütüphanesi'ne benzediği ileri sürülmüştür. Oysa bu iki yapı arasında önlerindeki revak elemanı ve işlevlerinin dışında bir ortaklıktan söz etmek imkansızdır. Köprülü Kütüphanesi, kare plan üzerine tek kubbeli yapısı ve önündeki revakıyla Erken Osmanlı devrinden beri bildiğimiz tek kubbeli -revaklı cami ve mescitlerin plan tipine dayanır.

Buna karşılık III. Ahmet Kütüphanesi; kubbeyle örtülü orta mekana açılan üç eyvanlı şemasıyla Klasik Osmanlı dönemi köşk planlarından ilham almıştır. Bu ilişkiyi görmek için pek de uzağa gitmeden Topkapı Sarayı bünyesindeki köşklere bakmak yeterli olacaktır. Bu açıdan Topkapı Sarayı́ndaki Yalı Köşkü (M.1592) sofası, Revan Köşkü (1635), Bağdat Köşkü (1638) ve Sepetçiler Köşkü (M.1643) divanhanesi ile bugün mevcut olmayan Beşiktaş sarayında Çinili Köşk'ün (1679) divanhanesi, yeterli fikir vermektedir.51

Ayşe Yetişkin Kubilay, 18. ve 19. yüzyıl İstanbul vakıf kütüphanelerini tipolojik bakımdan dört gruba ayırır ve III. Ahmet Kütüphanesi'ni, merkezi kubbeli tasarımıyla üçüncü grup içinde değerlendirerek bunun yeni bir tip olduğunu ve kendinden sonraki bazı kütüphanelere örnek olduğunu belirtir.52 III. Ahmet Kütüphanesi bize göre, Osmanlı köşk mimarisine ve geleneksel orta sofalı-aksiyal dört eyvanlı geleneğe dayanan üç eyvanlı tasarımıyla; Kubilay'ın vurguladığı biçimde kendinden sonra inşa edilecek olan Fatih'teki I. Mahmut Kütüphanesi (1742), Ragıp Paşa (1763), Murad Molla (1775) ve Esad Efendi (1848) kütüphanelerine esin kaynağı olmuştur.53 Bununla birlikte III. Ahmet'in yapısı; Topkapı Sarayı içinde yer alması, sadece saray mensuplarına açık olması ve personelle ilgili şartların saray teşkilâtının işleyişine uygun düzenlenmesi bakımlarından diğer vakıf kütüphanelerden ayrılmaktadır.54

Yukarıda çini süsleme bahsinde anlatıldığı biçimde, kütüphaneye ait M.1719 tarihli inşaat defterine göre; yapının iç dekorasyonu için İstavroz bahçesinden, Boğaziçinden, Kara Mustafa Paşa Yalısı'ndan ve Kandilli bahçesinden çiniler getirilmişti.55Defterde işaret edilen Boğaziçindeki yapıların, İstavroz Kasrı (16.yy. ikinci yarısı), Şevket-âbâd Sarayı (17.yy. ilk çeyreği) ve Kandilli bahçedeki Nev-âbâd Sarayı (17.yy. ikinci çeyreği) olmaları mümkündür. Kara Mustafa Paşa Yalısı olarak zikredilen bina ise; paşanın Emirgan'daki yalısı (17.yy.) olmalıdır.

Bu arşiv belgesindeki kayıttan hareketle en az dört ayrı yapıdan alınmış çinilerin kullanıldığı kütüphanedeki çini kaplamalar kompozisyon özellikleriyle altı farklı gruba ayrılmaktadırlar. Bunların tümü sıralt tekniğinde imâl edilmiş Klâsik üslûpta 17.yy. çinileridir. Bu çinilerin 17. Yüzyıldan kaldıkları konusunda sanat tarihçiler arasında görüş birliği bulunduğu söylenebilir.

50 G. Goodwin, a.g.e., s.470.

51 Bkz.;S. H. Eldem, Köşkler ve Kasırlar I, s.173-357.

52 Ayşe Yetişkin Kubilay, “18. ve 19. Yüzyıl İstanbul Vakıf Kütüphaneleri Üzerine Tipolojik Bir Değerlendirme”, Osmanlı Mimarlığının 7 Yüzyılı "Uluslarüstü Bir Miras", Yapı Endüstrisi Merkezî Yayınları, İstanbul.1999, s.153.

53 Ayşe Yetişkin Kubilay, a.g.m.,s.153.

54 İsmail E. Erünsal, "Osmanlılarda Kütüphane ve Kütüphaneci Geleneği”, Osmanlı, C.11, Yeni Türkiye Yayınları, Ankara1999, s.707.

55 S.H. Eldem, Köşkler ve Kasırlar, II, s.195. 
Yapıda güneydoğu eyvanın güney köşesindeki çiniler, İstanbul Sultan Ahmet Camii'nin mahfilindeki örneklere yaklaşırlar. Giriş cephesi ve hünkâr eyvanındaki çintemanili bordürün neredeyse aynıları İznik Eşrefî Rûmî minaresindeki onarım işi çinilerde (M.16191629) karşımıza çıkmaktadır. Kuzeybatı eyvanındaki bordür çinileri de Eşrefî Rûmî minaresindeki söz konusu onarım çinilerini hatılatırlar. Bu eyvanda bordür çinilerinin kuşattı̆ı yüzeyleri kaplayan çinilerin neredeyse aynıları, İstanbul Ayasoyfa Camii'ndeki M.1643 tarihli panoda da göze çarpmaktadır.Yapıyı kaplayan çinilerin motif, renk ve kompozisyon özellikleri bir bütün olarak değerlendirildiğinde; bunların esas olarak 17. Yüzyıl ilk yarısına uygun düşen bir üslûp sergiledikleri ileri sürülebilir. Bunların henüz klâsik kalitenin bozulmadığı bir evrede yapılmış çiniler oldukları bellidir. Sadece pencere iç duvarlarını kaplayan çiniler 17. Yüzyılın ikinci yarısına tarihlenen bir yapıdan getirilmiş olabilirler. Çünkü bunlar kompozisyon ve kalite bakımlarından daha çok İstanbul Yeni Cami (M.1663) çinileriyle benzeşmektedirler.

İstisnai olarak bir kaç parça çini, hem sayıca azlıkları hem de üslûp özellikleriyle ilk alt gruptakilerden tamamen farklıdırlar. Bunlar yapının ilk inşa aşamasında kullanılmış çiniler olmayıp; muhtemelen onarımlardan birisi sırasında pencere içlerine konulmuşlardır. Bunlardan renkli sır tekniğinde olan 15-16. Yüzyıldan kalmadır. Diğer ikisi ise Avrupa'dan ithal çinilere benzemekle birlikte Avrupa işlerine öykünen Kütahya üretimi de olabilirler. Bu çinilerin en son yapılan restorasyon sırasında kaldırılmış olduklarını düşünüyoruz.

Sonuç olarak; III. Ahmet'in Topkapı Sarayındaki kütüphanesi; Osmanlı köşk tiplerinden ilham alan bodrum katlı planı, mermer malzemeyle kaplı anıtsal cepheleri, ilginç çeşme yapılarıyla ilişkilendirilmiş revakı; zengin alçı (ştuko) ve çinilerle bezeli iç mekanları, sedef kakmalı pencere kepenkleri, üst sıra pencerelerinin revzenleri ve içeride mermer sütunlar, başlıklar ve bunların üst kısımlarındaki plastik ögeleriyle Lâle devrini en gösterişli biçimde yansıtan yapılardan birisidir. Fakat iç cepheleri örtü sistemine kadar kaplayan çinilerin Lâle devrinden önceye ait yapılardan alınmış klâsik üslupta çiniler oluşu ilginç bir tezat oluşturmaktadır. Bu çinilerin büyük çoğunluğu 17. Yüzyıl ilk yarısına ait görünürken, bir grup çini 17. Yüzyılın ikinci yarısına verilebilirler. İstisnai nitelikteki üç parça çininin ise onarımlar sırasında yapıya iliştirildiklerini düşünüyoruz. 


\section{KAYNAKÇA}

ARLI,Belgin Demirsar - ALTUN,Ara, Anadolu Toprağının Hazinesi Çini: Osmanlı Dönemi, Kale Grubu Kültür Yayınları, İstanbul 2008.

ASLANAPA, Oktay, Osmanlı Mimarisi, İnkılâp Kitâbevi, İstanbul 1986.

ATIL, Esin, Levni ve Surname Bir Osmanlı Şenliğinin Öyküsü, Çev:Zeynep Rona Koçbank Yayınları, İstanbul 1999.

CANCA, Gülçin, Bir Geçiş Dönemi Olarak İstanbul'da 3.Ahmet Devri,(Mimar Sinan Güzel Sanatlar Üniversitesi, Sosyal Bilimler Enstitüsü, Yayınlanmamış Doktora Tezi), İstanbul 1999.

DEMIRiz,Yıldız, "17. Yüzyıl Çinilerinde Değişen Desen Anlayışı", 17. Yüzyıl Osmanlı Kültür ve Sanat, Sempozyum Bildirileri (19-20 Mart 1998), İstanbul 1998, s.77-84.

ELDEM, Sedat Hakkı - AKOZAN, Feridun, Köşkler ve Kasırlar,l, Devlet Güzel Sanatlar Akademisi, İstanbul 1969. ELDEM, Sedat Hakkı - AKOZAN,Feridun, Topkapı Sarayı, Kültür ve Turizm Bakanlığı Yayını, İstanbul 1982.

ELDEM,Sedat Hakkı, Köşkler ve Kasırlar,ll, Devlet Güzel sanatlar Akademisi, İstanbul 1974.

ERÜNSAL, İsmail E. Osmanlı Vakıf Kütüphaneleri, Atatürk Kültür Merkezi Yayını, 2.Baskı,Ankara 1991.

ERÜNSAL, İsmail E., “Osmanlılarda Kütüphane ve Kütüphaneci Geleneği”, Osmanlı, C.11, Yeni Türkiye Yayınları, Ankara1999, s.699-719.

EYiCE, Semavi "Ahmet III Kütüphanesi",Dünden Bugüne İstanbul Ansiklopedisi, C.1, İstanbul 1993, s.115-116.

GAUTIER, Theophile, Constantinopole, Paris 1891.

GOODWiN, Godfrey, Osmanlı Mimarlığı Tarihi,Çev: Müfit Günay,Kabalcı Yayınevi, İstanbul 2012.

IREPOĞLU, Gül ,Levnî: Nakış,Şiir, Renk, T.C. Kültür Bakanlığı Yayını, İstanbul 1999.

KARABUDAK,Asuman, 18.yüzyıl Tarihi Yarımada Kütüphane Yapıları Koruma Sorunları ve Öneriler,(Mimar Sinan Üniversitesi Fen Bilimleri Enstitüsü Yayınlanmamış Yüksek Lisans Tezi), İstanbul 2006.

KARAHASAN, Ümran, Topkapı Sarayı Müzesi Cumhuriyet Dönemi Restorasyonları, (Yıldız Teknik Üniversitesi, Fen Bilimleri Enstitüsü, Yayınlanmamış Doktora Tezi), İstanbul 2005.

KARAL, Enver Ziya, “Ahmet III”, İslam Ansiklopedisi,C.1, 2.Baskı, Eskişehir 1997, s.165-168.

KOÇU, Reşat Ekrem, Topkapu Sarayı, İstanbul 1960.

KUBAN, Doğan, Osmanlı Mimarisi, YEM yayınları, İstanbul 2007.

KUBiLAY,Ayşe Yetişkin, "18. ve 19. Yüzyıl İstanbul Vakıf Kütüphaneleri Üzerine Tipolojik Bir Değerlendirme”, Osmanlı Mimarlığının 7 Yüzyılı "Uluslarüstü Bir Miras", Yapı Endüstrisi Merkezî Yayınları, İstanbul.1999, s.149-153.

KÜÇÜKERMAN, Önder, Sanayi ve Tasarım Yarışında Bir Imparatorluk Iki Saray, Yapı Kredi Yayınları, İstanbul 2007.

NECiPOĞLU, Gülru, 15. 16. yüzyılda Topkapı Sarayı: Mimari Tören ve Iktidar, Çev.:R.Sezer,Yapı Kredi Yayınları, İstanbul 2007.

ORTAYLI, ilber, Mekanlar ve Olaylarıyla Topkapı Sarayı, Bank Asya Kültür Hizmetleri, İstanbul 2009.

ÖZ, Tahsin, “La Bibliothéque du Palais de Topkapı”, La Turquie Kemaliste, No.45, 1941, p.7-11.

ÖZ, Tahsin, "Topkapı Sarayı Müzesi Onarımları”, Güzel Sanatlar, S:6, 1949, s.6-74.

ÖZ,Illban, "Topkapı Sarayı Onarımları", Sanat, S:7, 1982, s.65-76.

PARDOE, Julia, Sultanlar Şehri İstanbul,Çev: M. Banu Büyükkal, Türkiye İş Bankası Kültür Yayınları, İstanbul 2010. Raşid Mehmed Efendi, Târihi Râşid ve Zeyli, C.Il, Haz: Abdülkadir Özcan v.d., İstanbul 2013.

Ahmet Refik, OnikinciAsr-ı Hicrîde İstanbul Hayat, (1689-1785), Enderun Kitâbevi, 2.Baskı,İstanbul 1988.

SAKAOĞLU,Necdet, Tarihi, Mekanları, Kitâbeleri ve Anıları ile Saray-ı Hümayun,Topkapı Sarayı, Denizbank Yayını, İstanbul 2002.

Silahdar Fındıkılı Mehmet Ağa, Nusretnâme,C.Il.,Sadeleştiren: İsmet Parmaksızoğlu, Milli Eğitim Basımevi, İstanbul 1966.

SÖZEN,Metin,Topkapı, Hürriyet Gazetecilik ve Matbaacılık A.Ş., İstanbul 1998.

ŞAHIN, Alime, İstanbul'daki Osmanlı Dönemi Kütüphaneleri Üzerine Bir Araştırma ve Hacı Beşir Ağa Kütüphanesi, (Yıldız Teknik Üniversitesi, Fen Bilimleri Enstitüsü, Yayınlanmamış Yüksek Lisans Tezi), İstanbul 1997.

ŞAHIN, Soner, Değişim Sürecinde Osmanlı Mimarlığı, III.Ahmet ve I.Mahmut Dönemi(1703-1754), (İstanbul Teknik Üniversitesi, Fen Bilimleri Enstitüsü, Yayınlanmamış Doktora Tezi), İstanbul 2009.

YENAL, Şükrü, "Topkapı Sarayı Müzesi Enderun Kitaplığı (Ahmet III. Kitaplığı)”, Güzel Sanatlar , S.6, 1949, s.85-90.

YILDIZ, Murat, "Türk Sivil Mimarisinin en Eski Yapılarından Amcazâde Hüseyin Paşa Yalısının Tarihî Serüveni", Türkiyat Mecmuası, C.21, İstanbul 2011, s.395-433. 


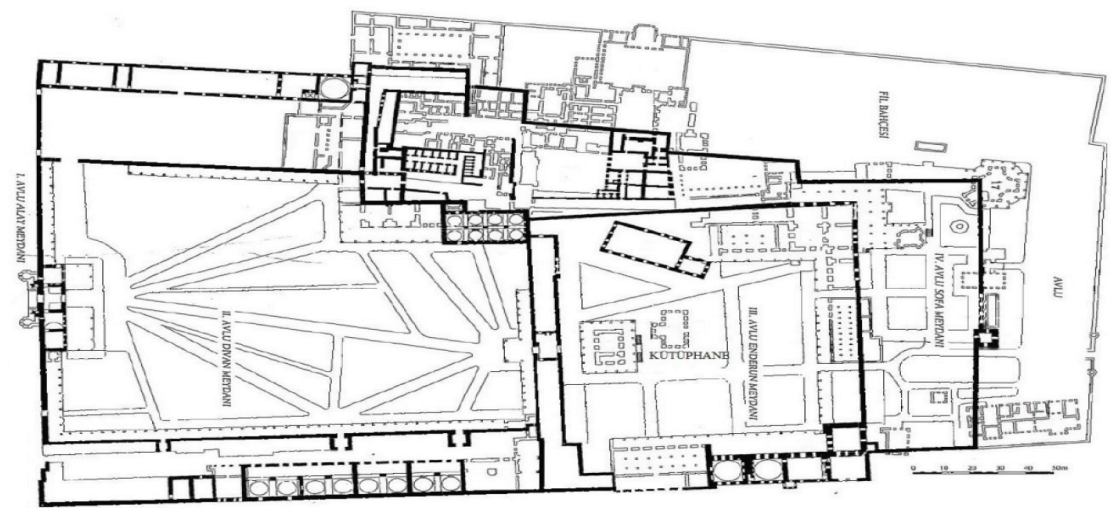

Şekil 1. Topkapı Sarayı Vaziyet Planı ( D.Kuban'dan)

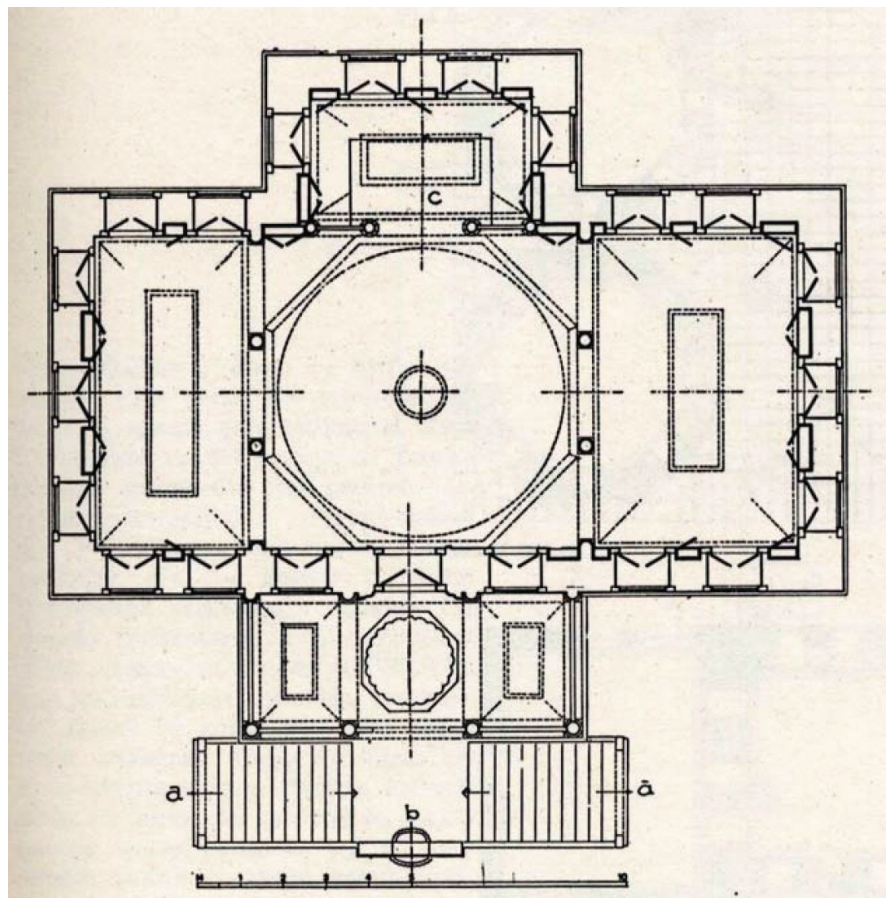

Şekil 2. Kütüphanenin restitüsyon planı (S.H. Eldem'den) 


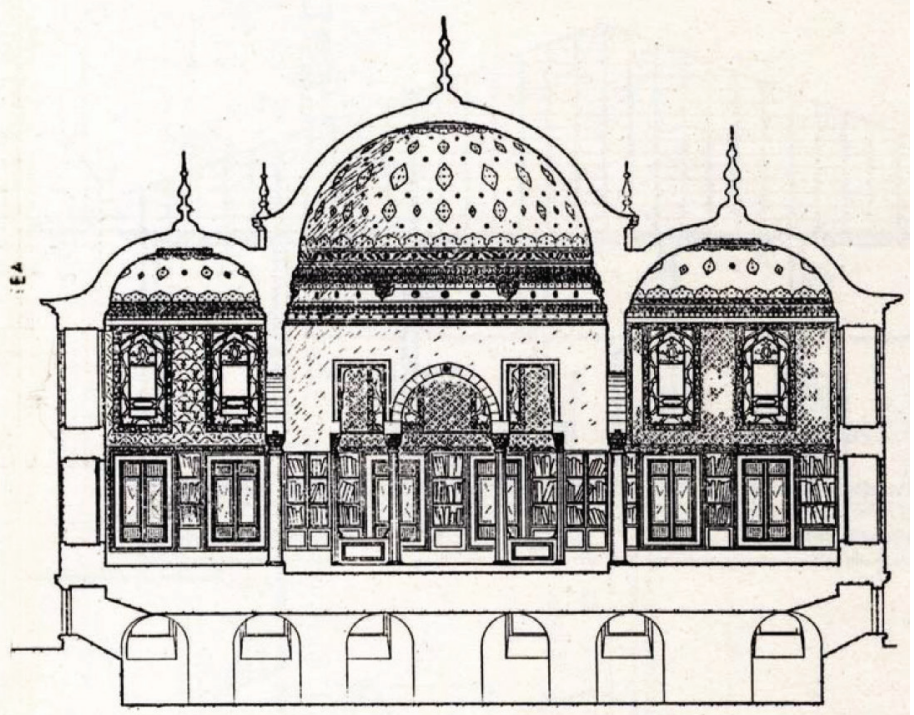

Şekil 3. Kütüphanenin restitüsyon kesiti (S.H. Eldem'den)

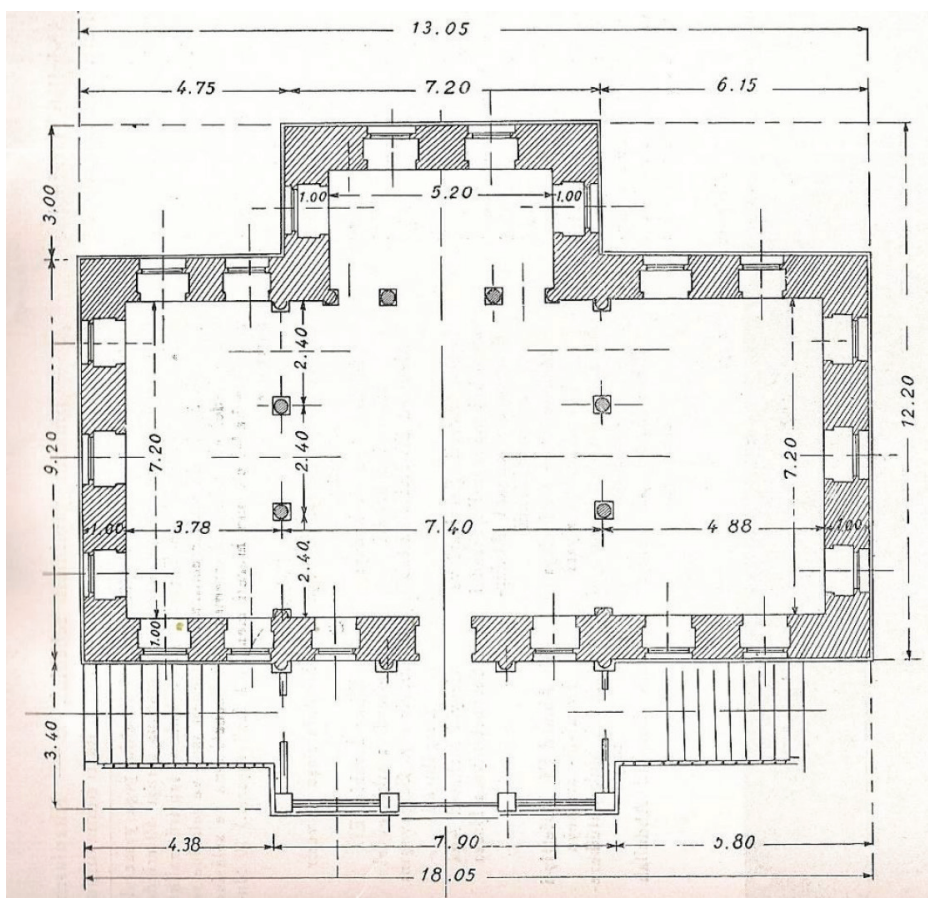

Şekil 4. Kütüphanenin rölöve planı (Ş.Yenal'dan) 


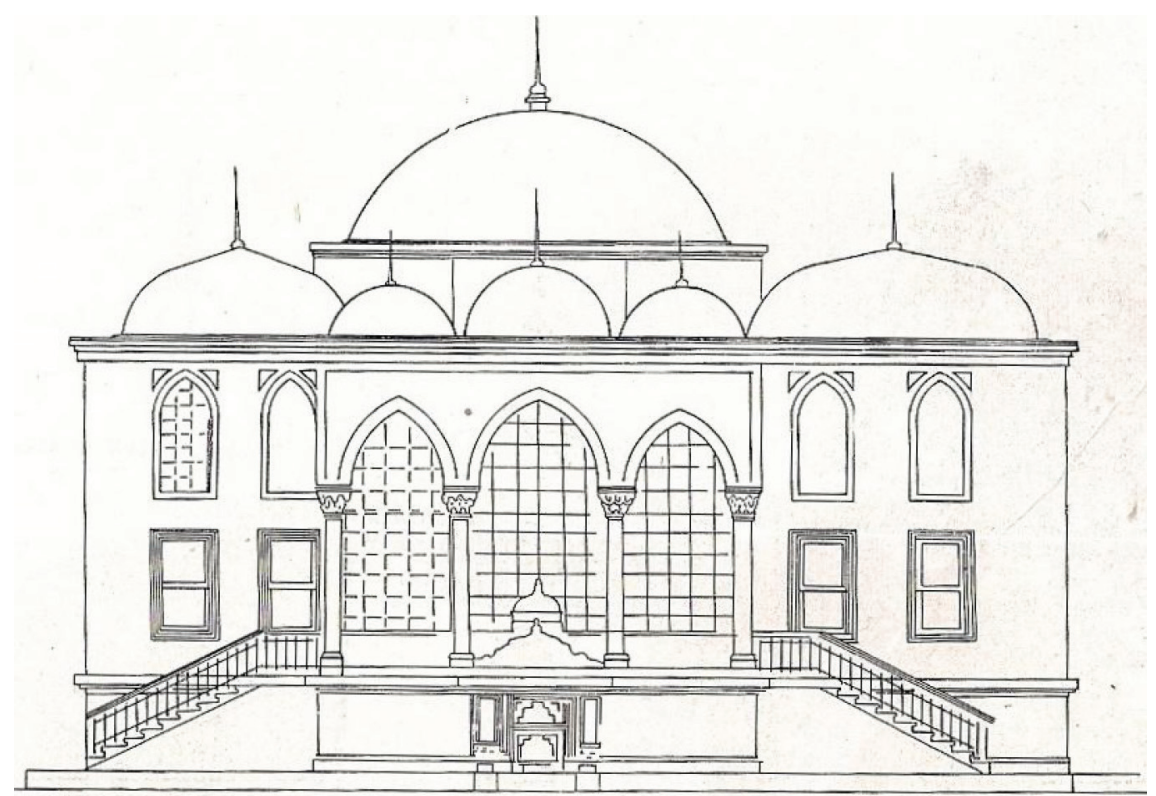

Şekil 5. Kütüphanenin cephe rölövesi (Ş.Yenal'dan)

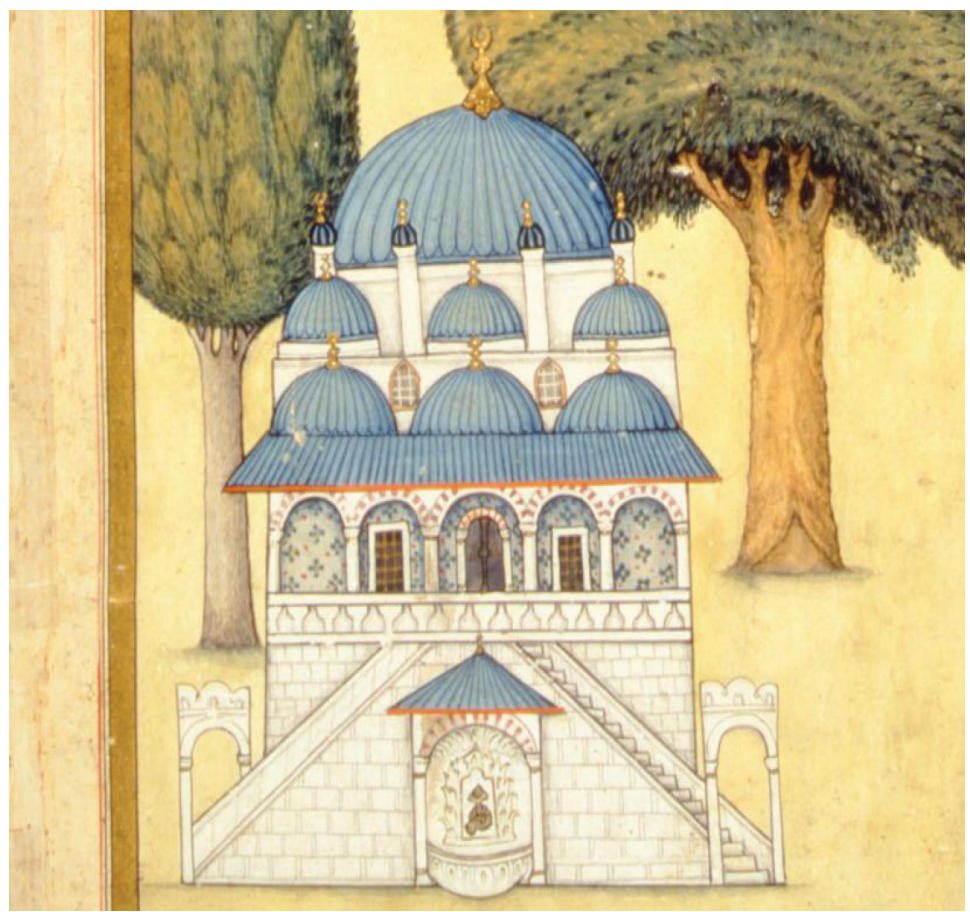

Resim 1. Levnî'nin minyatüründe kütüphane (G.Irepoğlu'dan) 


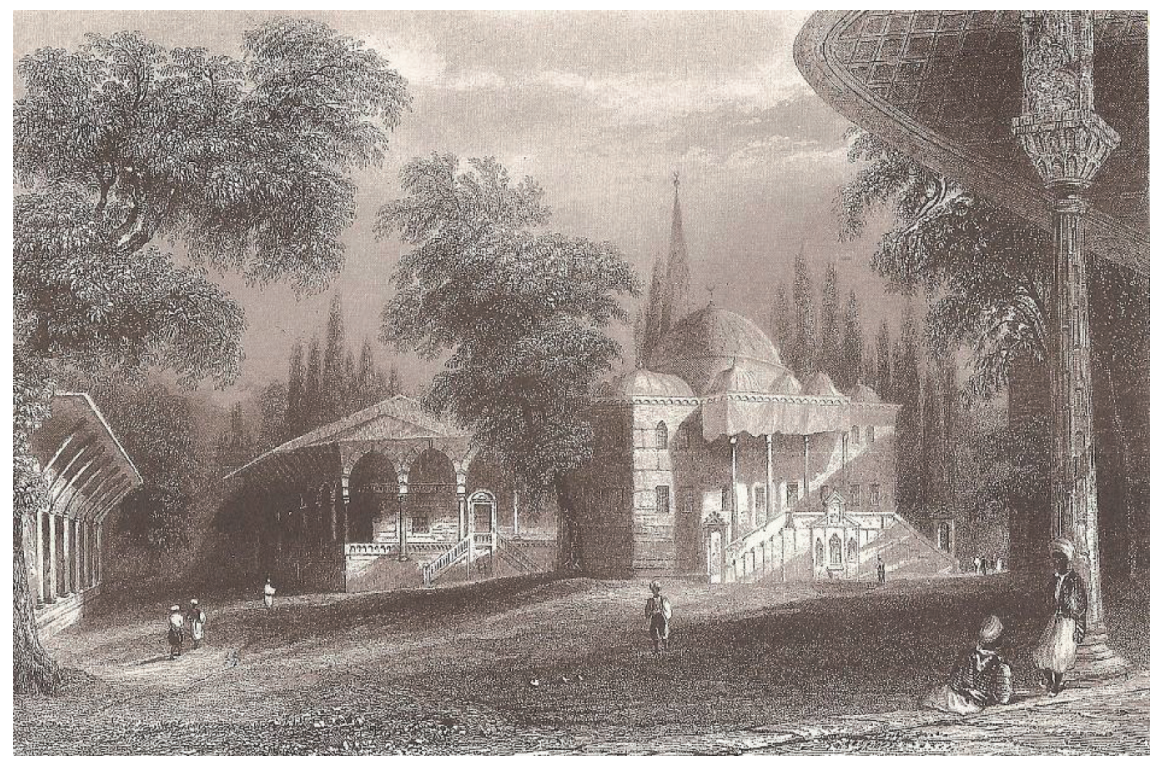

Resim 2. W.H. Bartlett'in gravüründe kütüphane

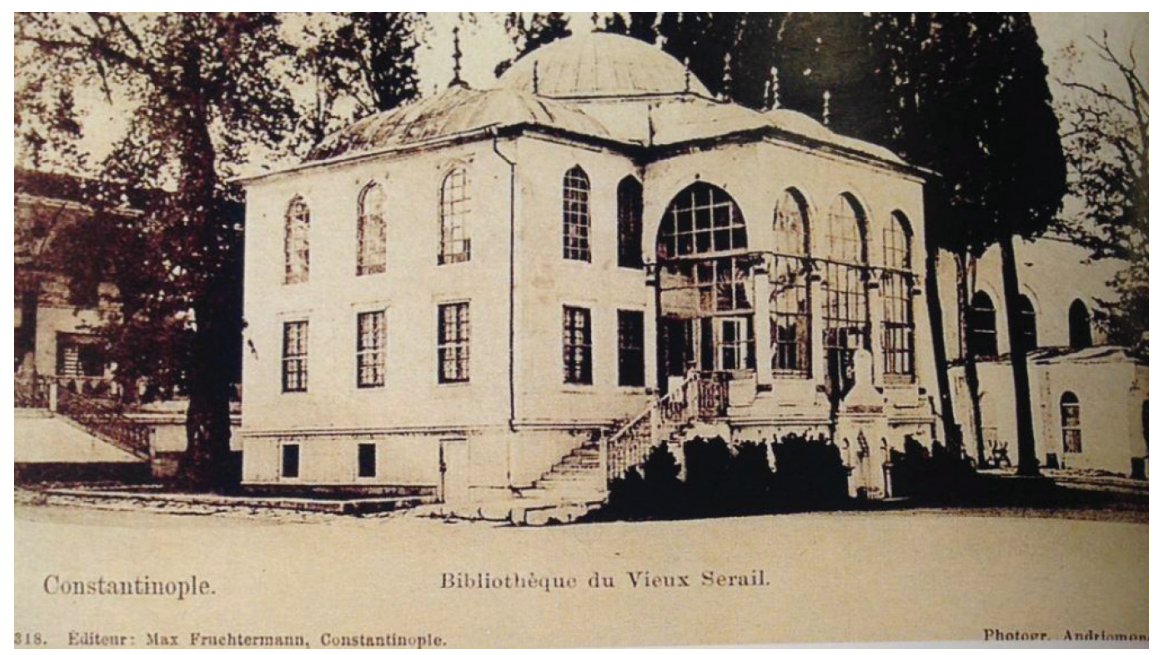

Resim 3. 1902 tarihli bir karpostalda kütüphanenin görünüşü (TSMA) 


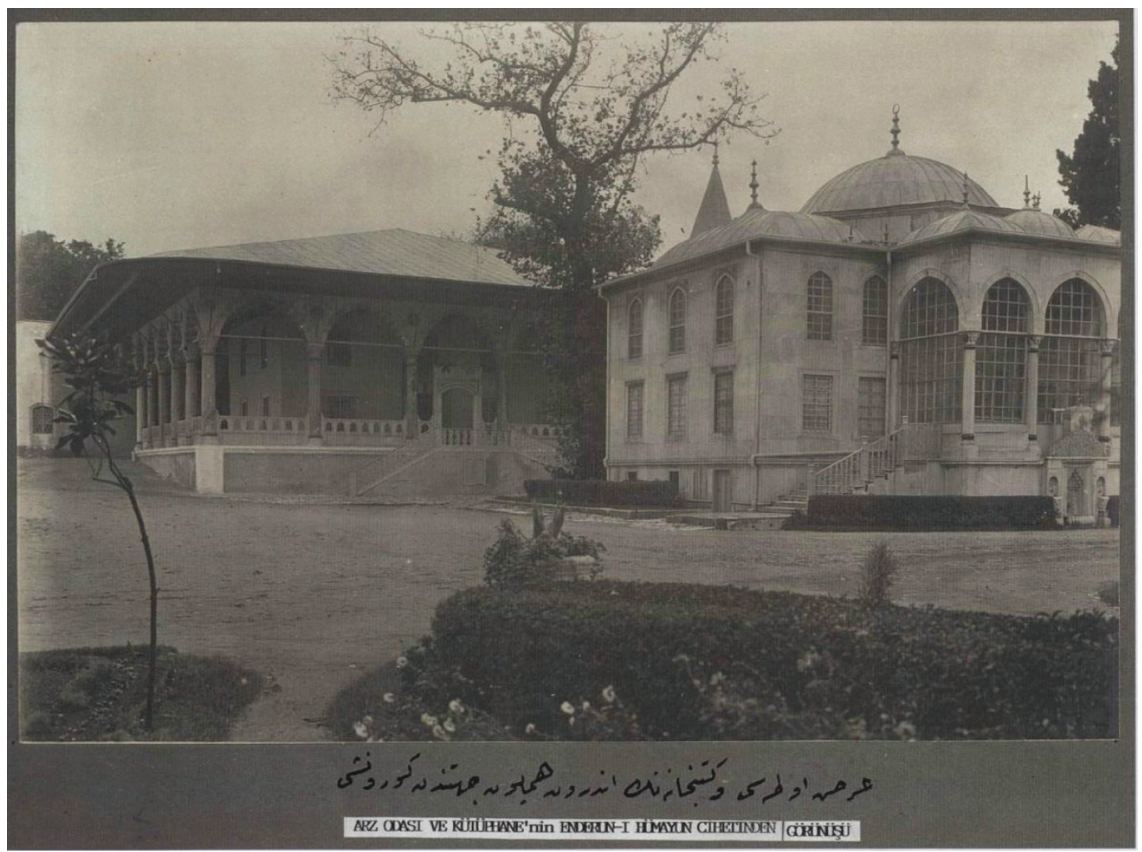

Resim 4. Eski bir fotoğrafta kütüphane (1920 tarihli) (TSMA)

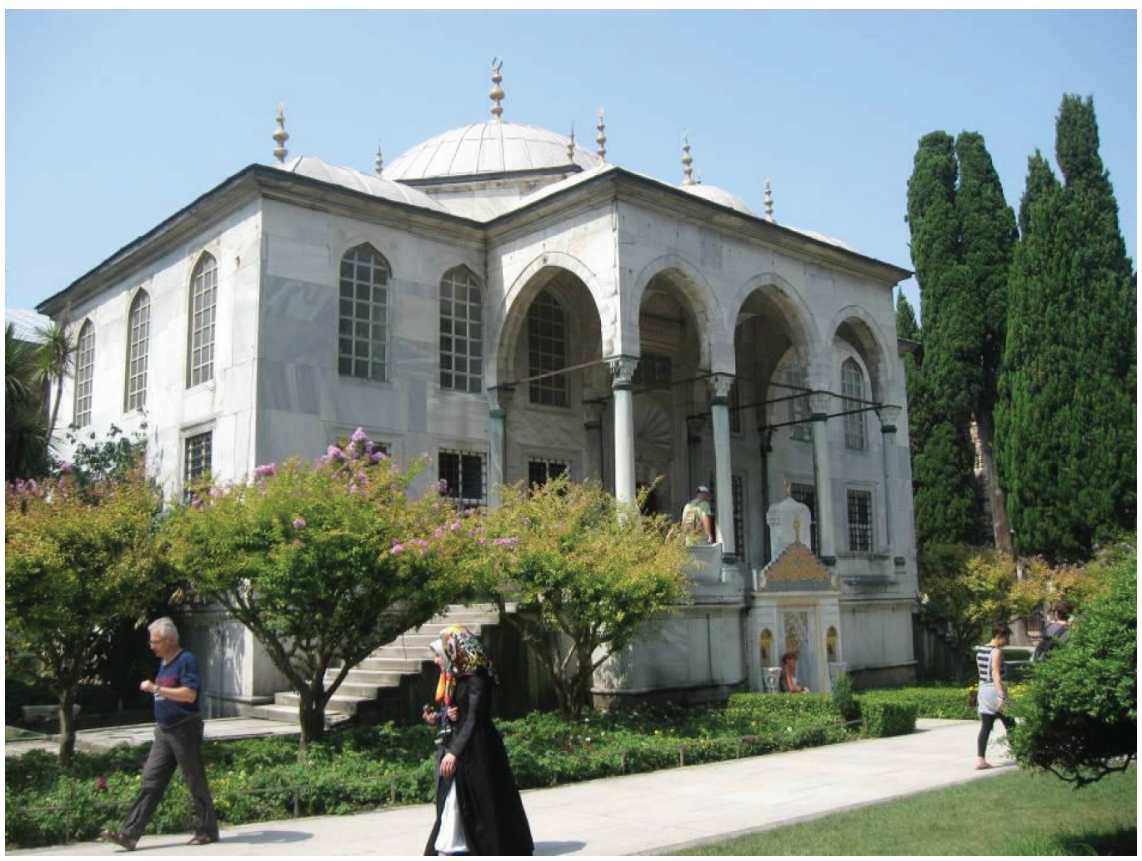

Resim 5. Kütüphanenin genel görünüşü (2018) 


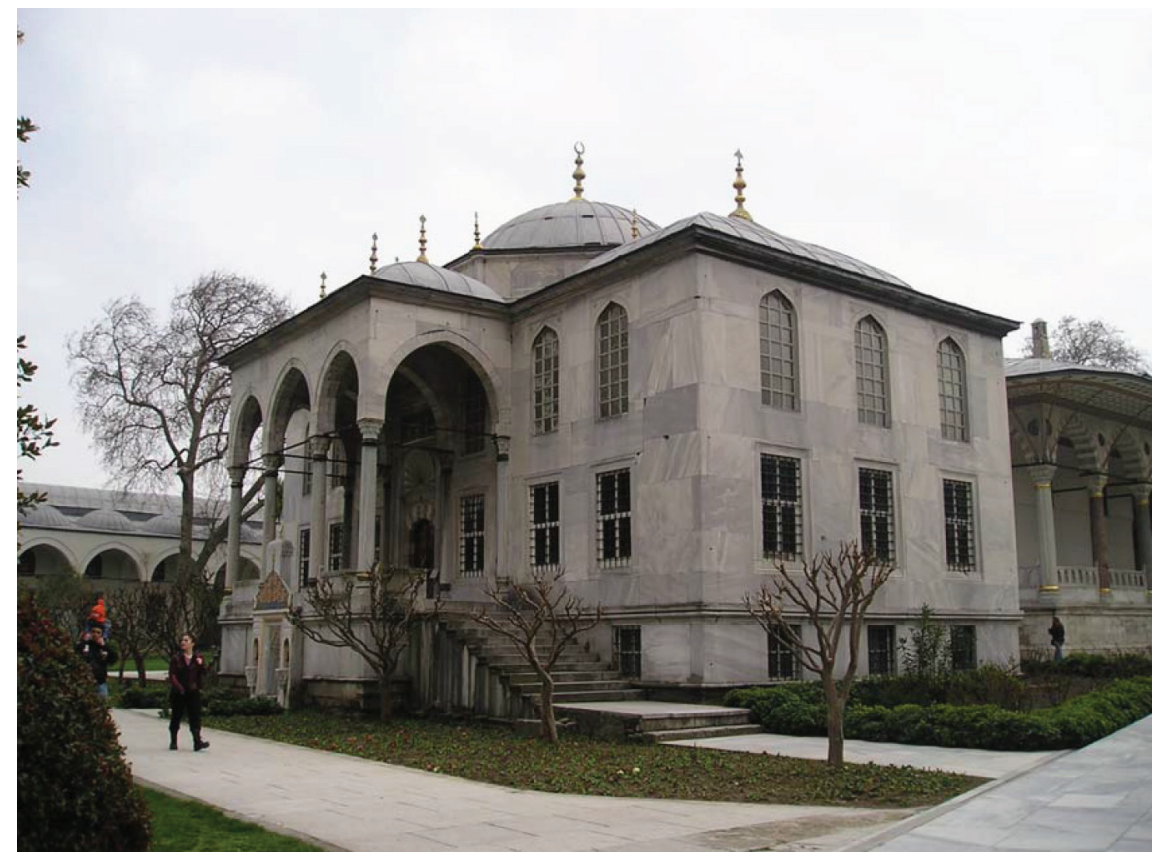

Resim 6. Kütüphanenin kuzeydoğu ve kuzeybat cepheleri

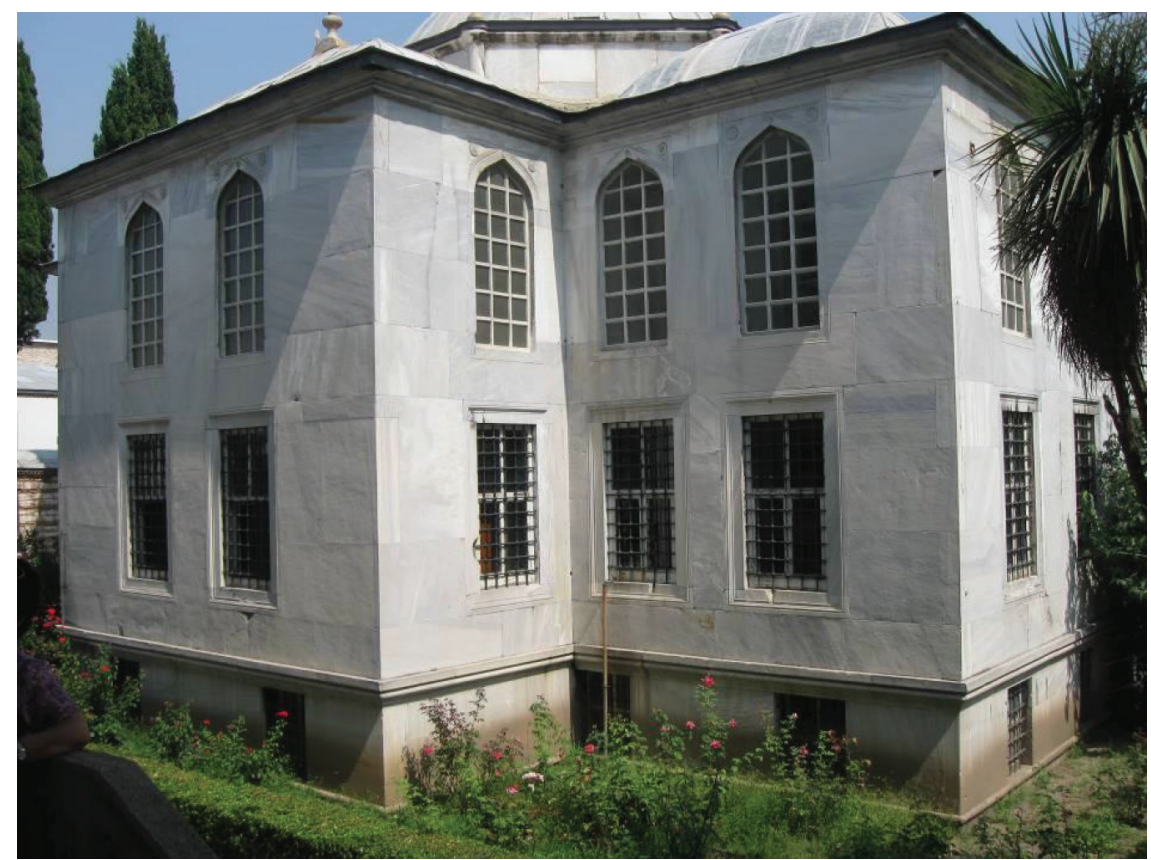

Resim 7. Kütüphanenin arka cephesi 


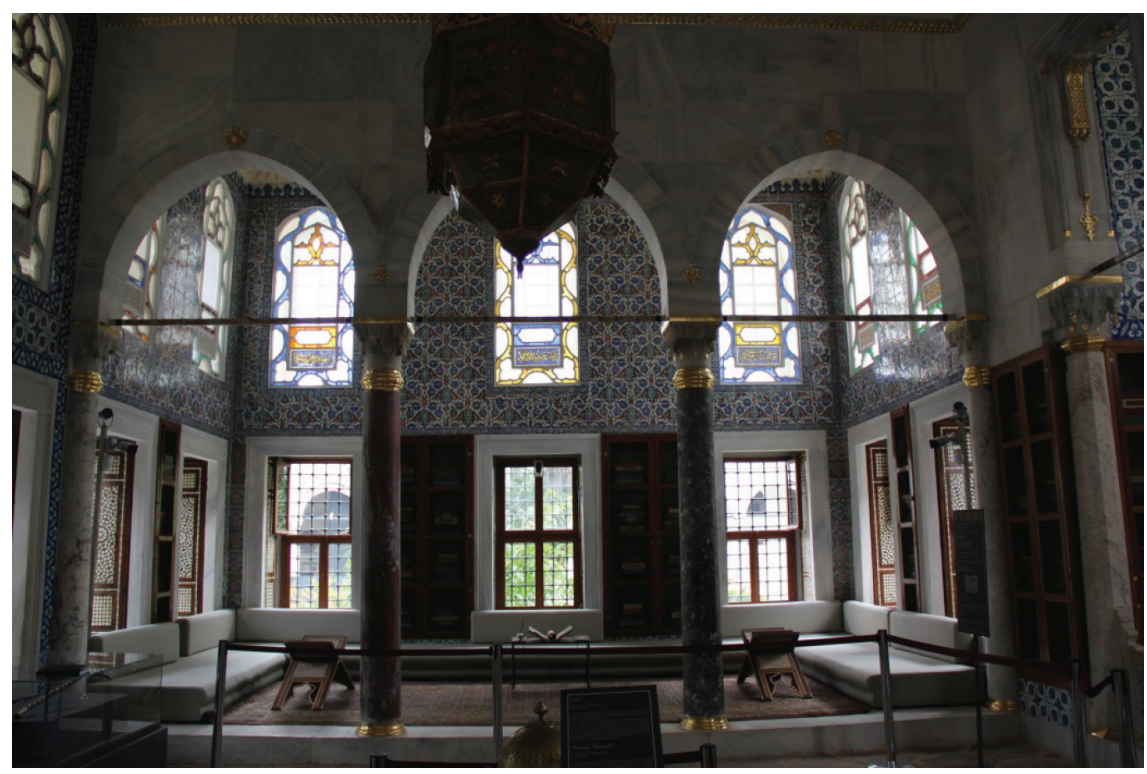

Resim 8. Güneydoğu eyvanı

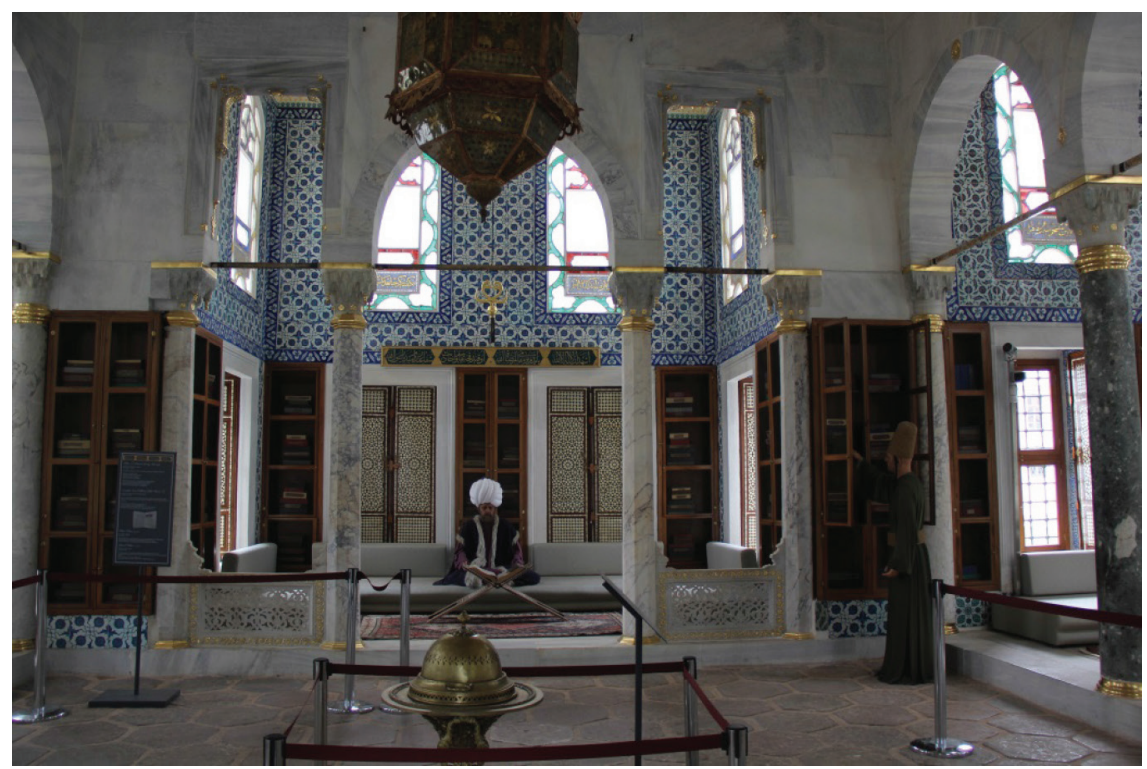

Resim 9. Güneybatı eyvanı (Hünkâr eyvanı) 


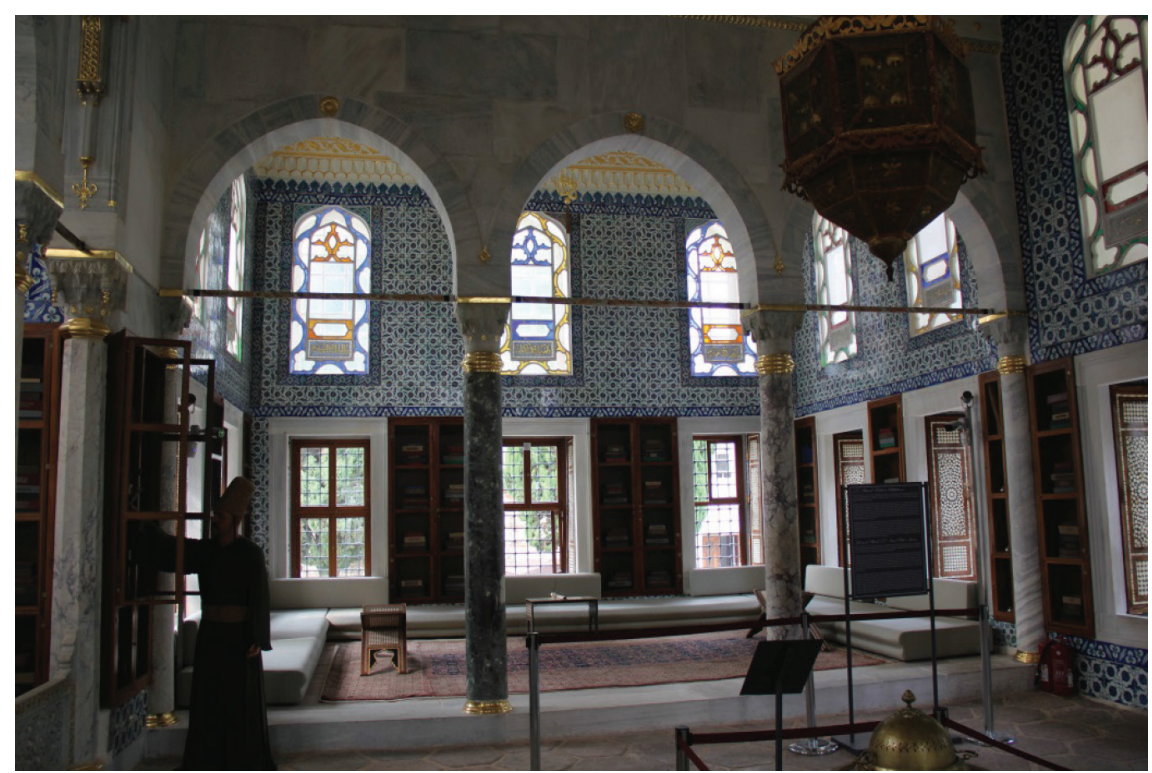

Resim 10. Kuzeybatt eyvanı

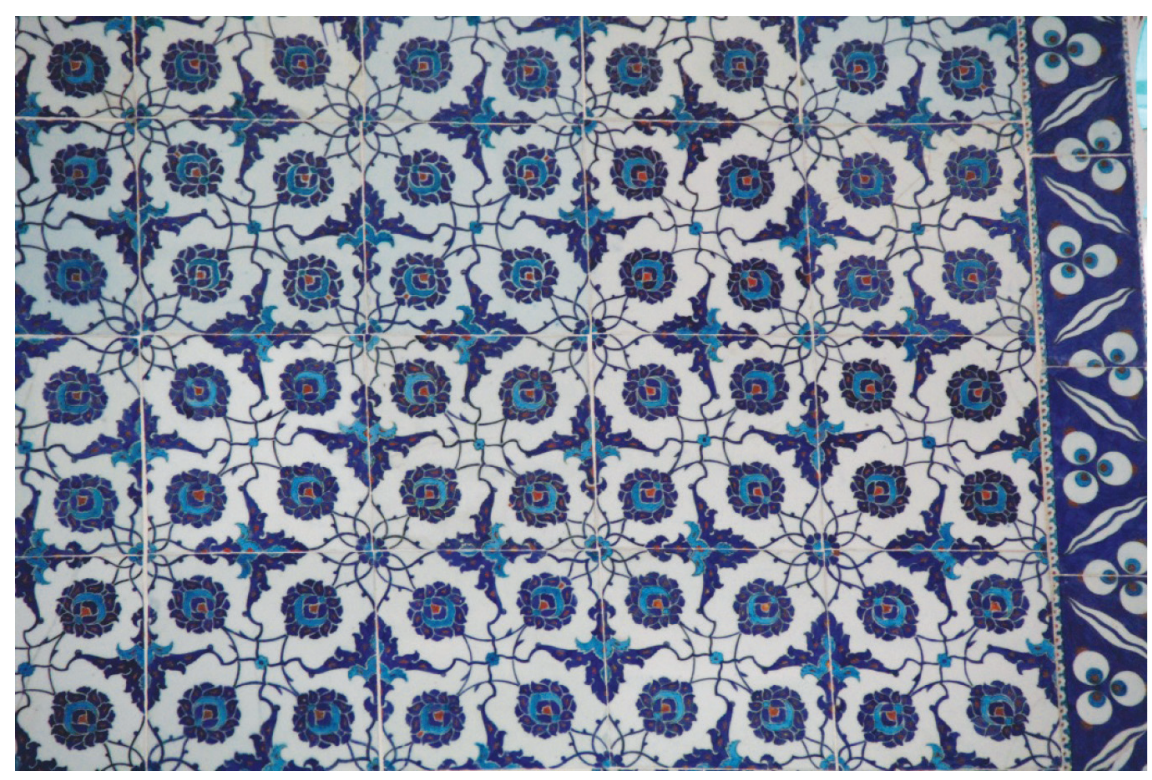

Resim 11. Giriş iç cepheden çini bezeme 


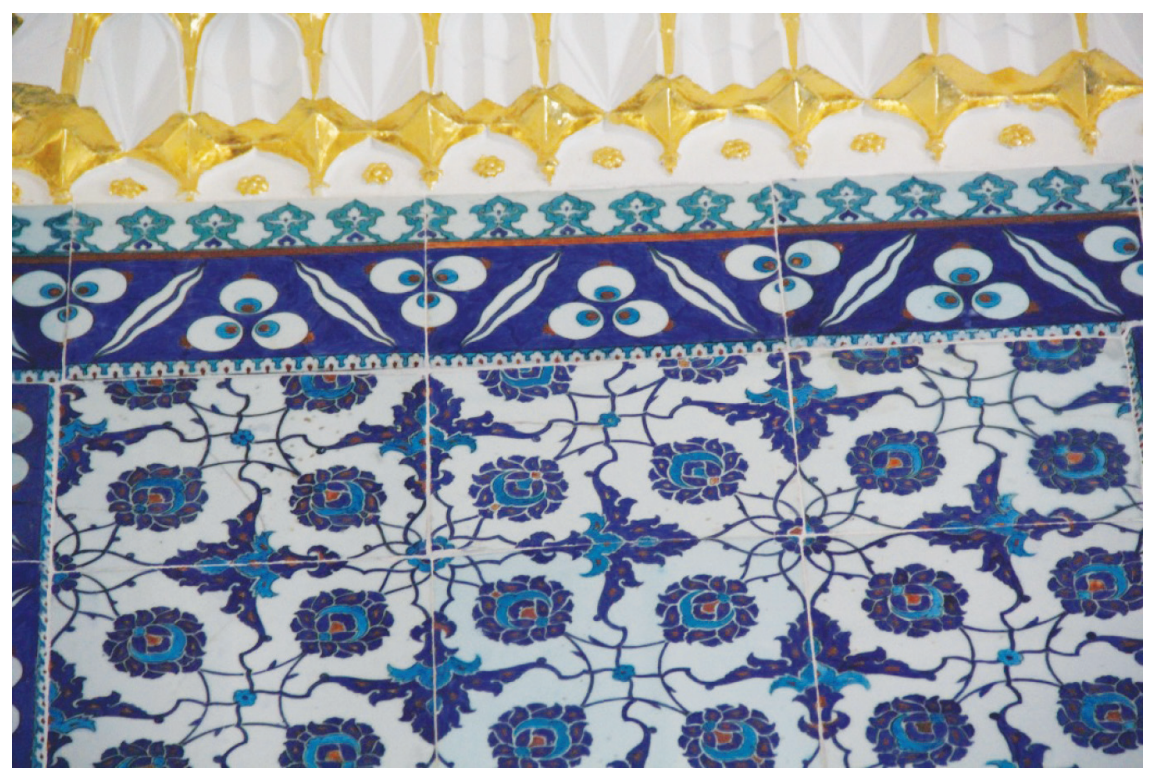

Resim 12. Hünkâr eyvanında çini kompozisyonu

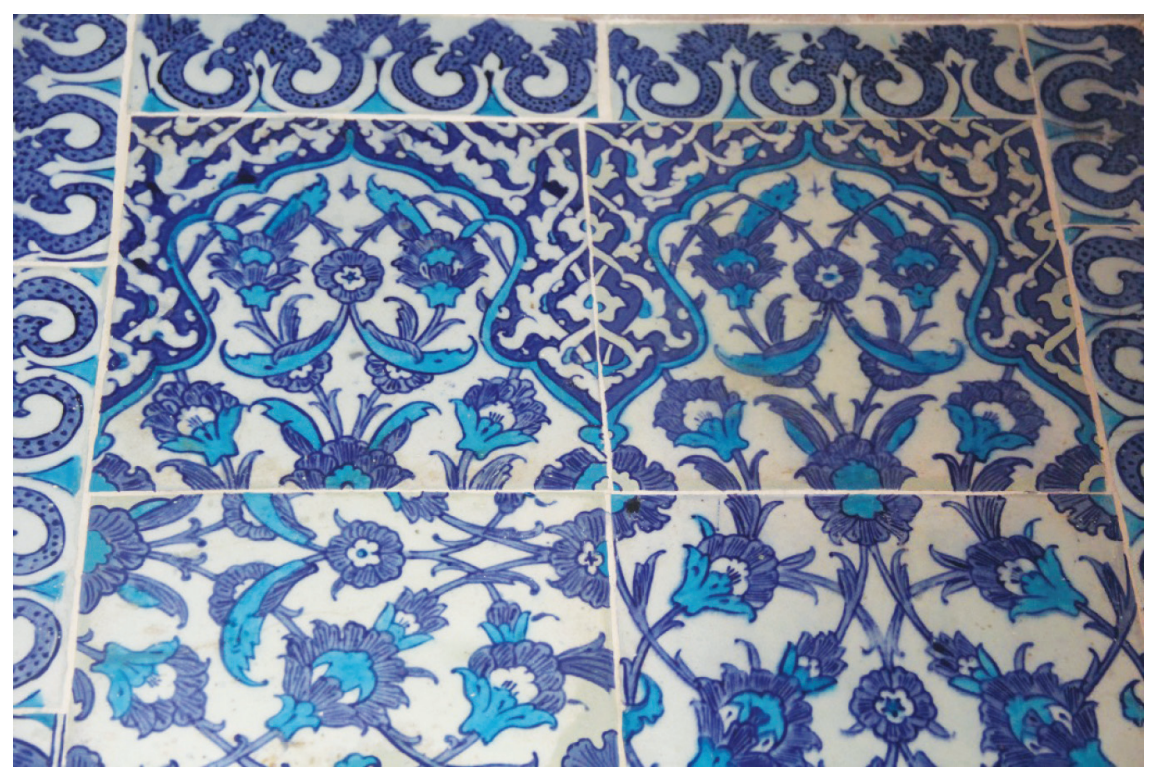

Resim 13. Giriş açıklığı duvar kalınlığını kaplayan çiniler 


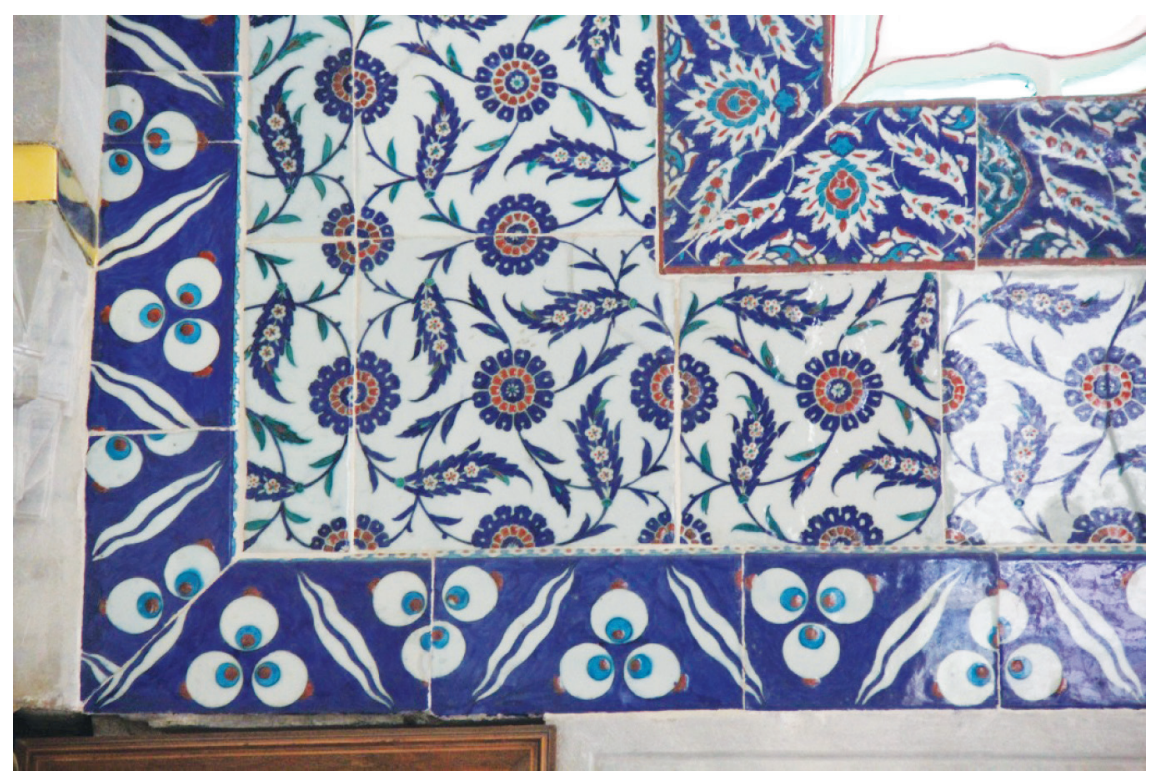

Resim 14. Kuzeybatt eyvanında çini düzeni

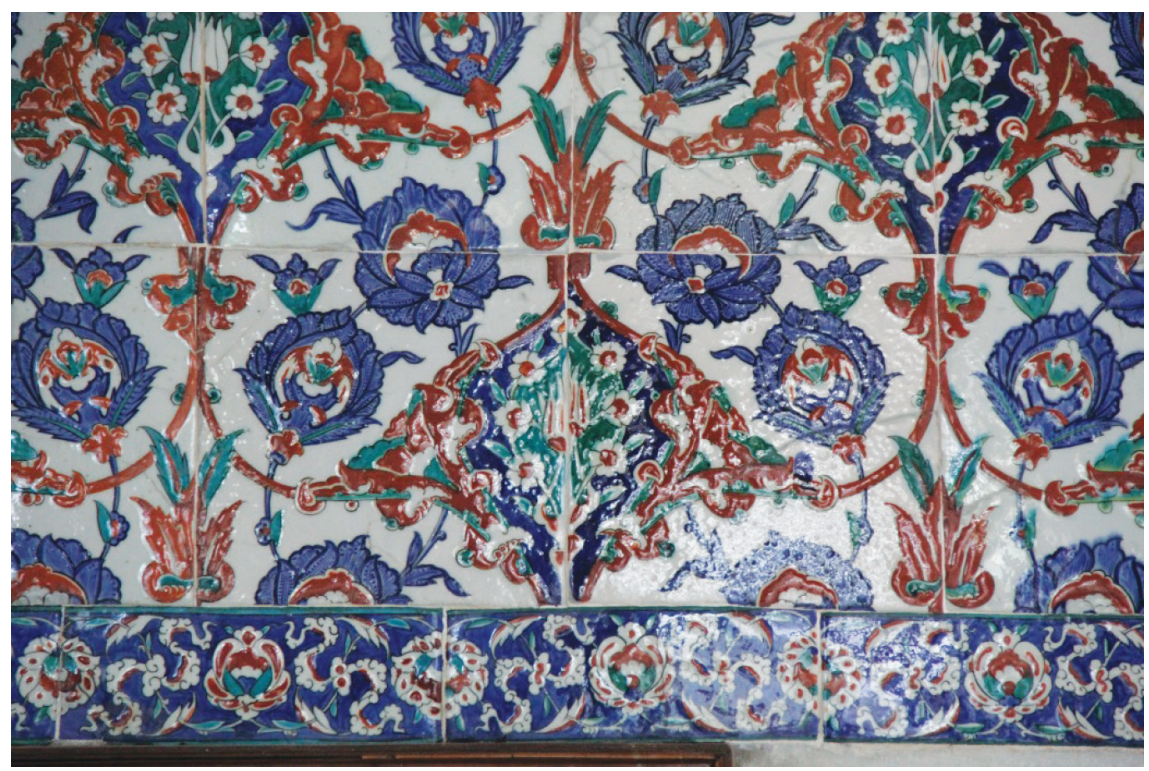

Resim 15. Güneydoğu eyvanında çiniler 


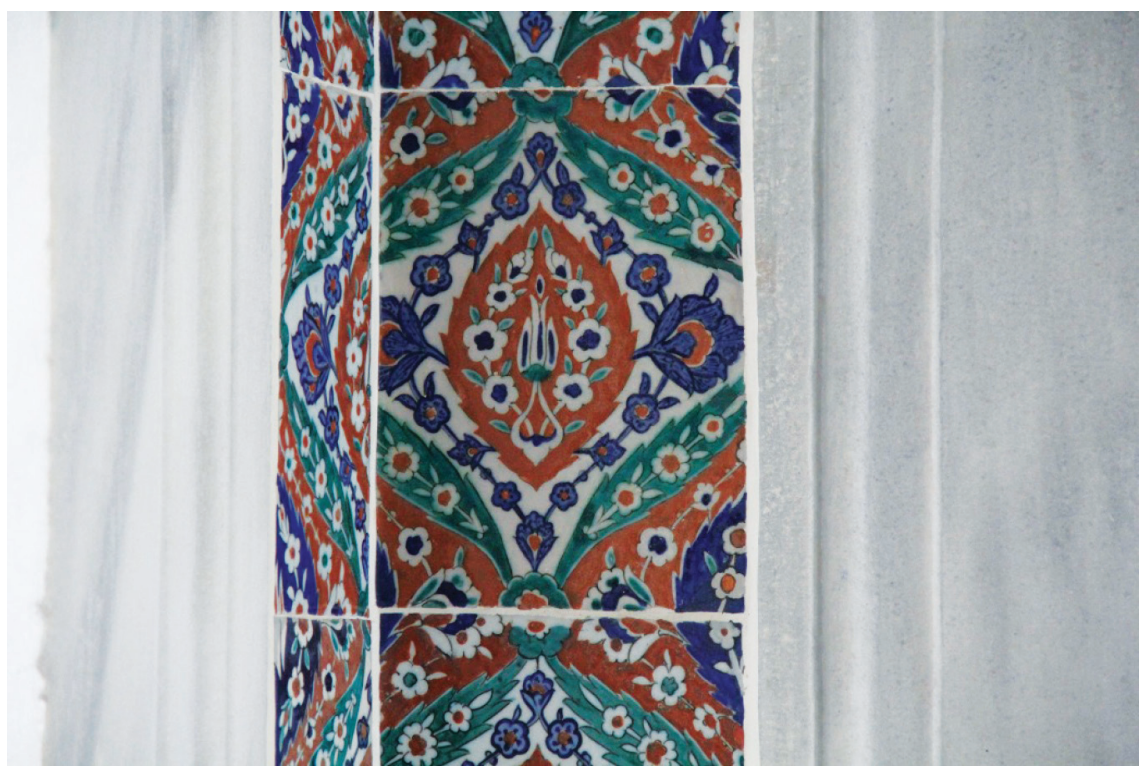

Resim 16. Güneydoğu eyvanı güney köşede çini bordür

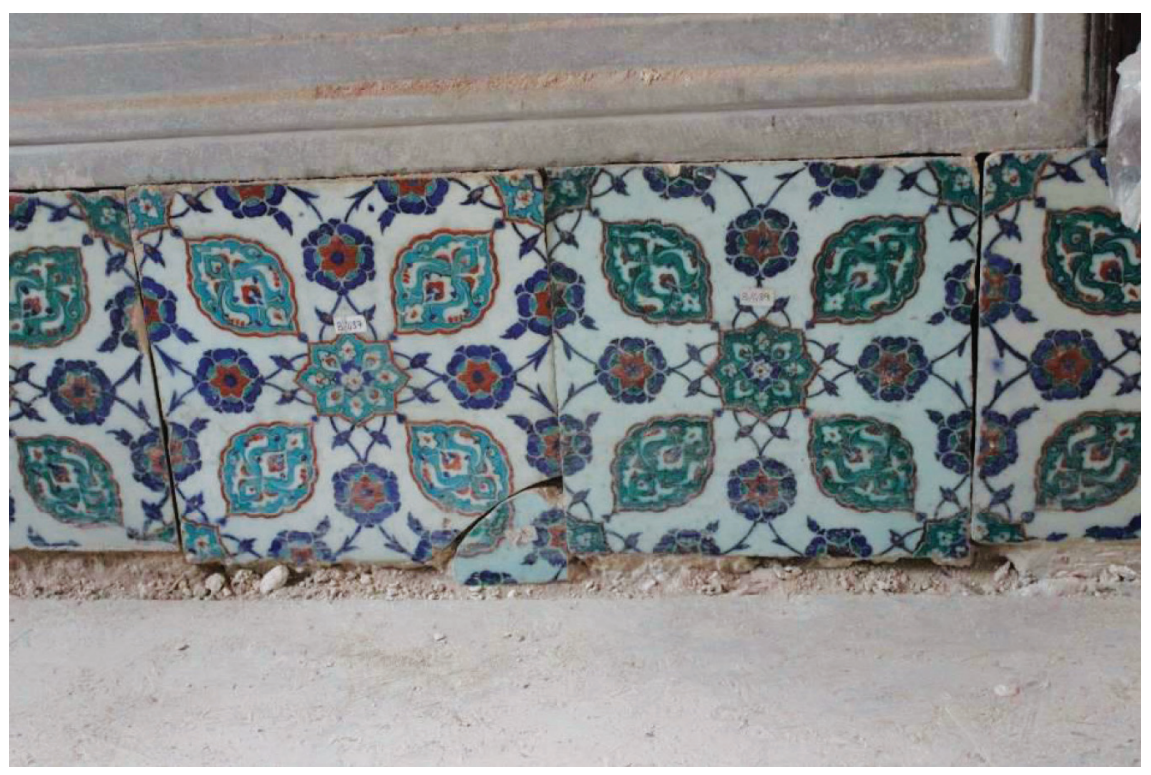

Resim 17. Yan eyvanların süpürgelik seviyesindeki çiniler 


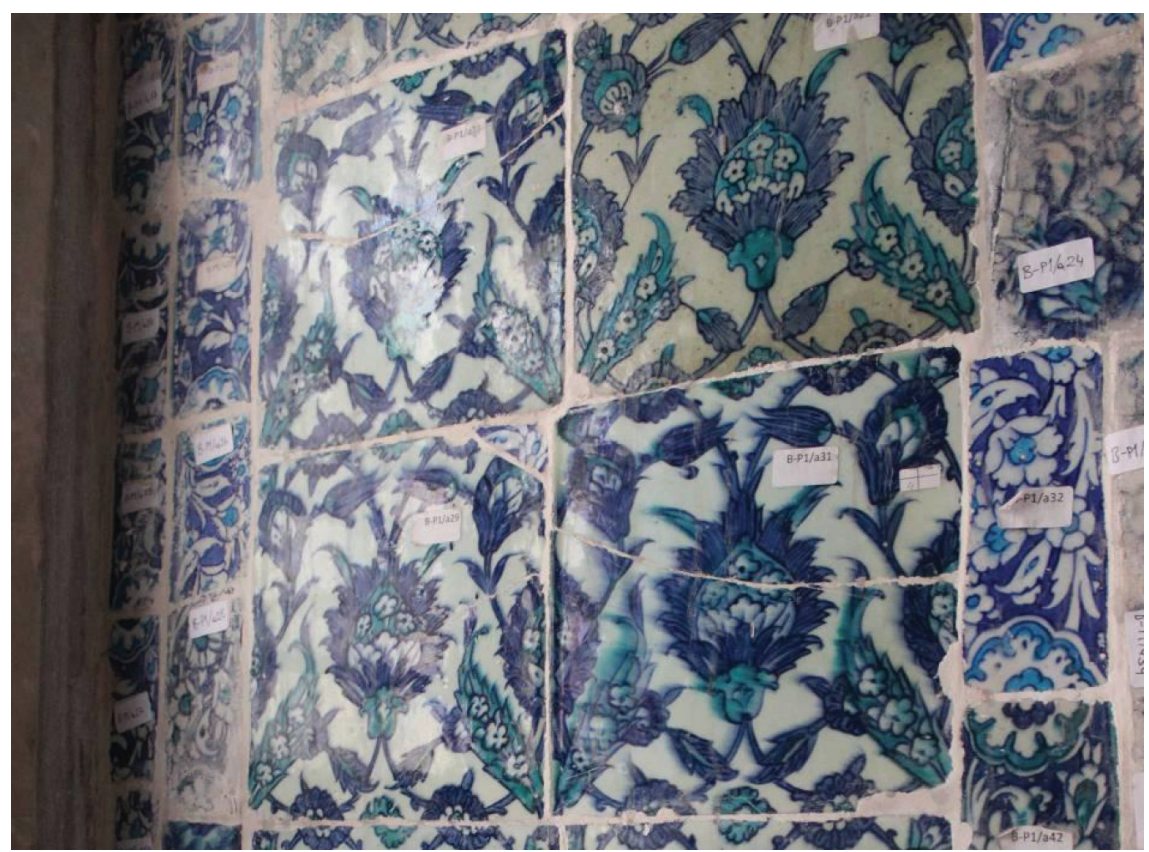

Resim 18. Pencere iç duvarlarındaki çiniler

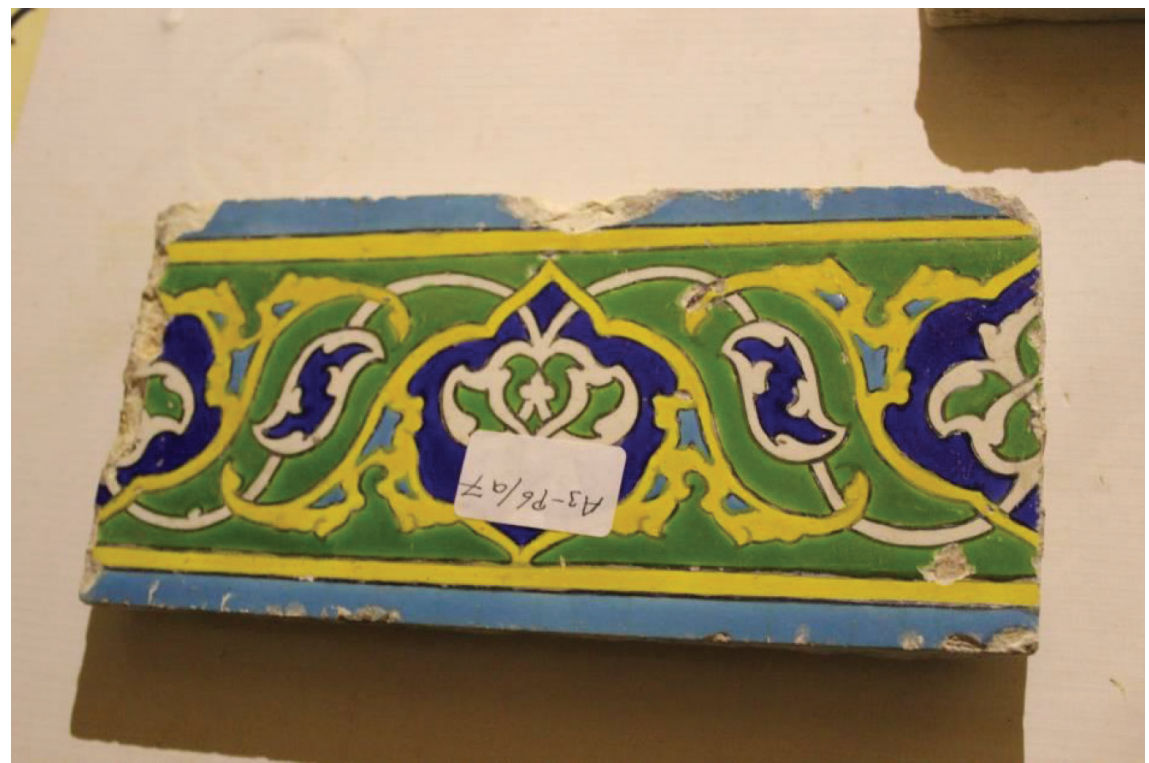

Resim 19. Renkli sır tekniğinde bordür çinisi 
Çanakkale Onsekiz Mart University International Journal of Social Sciences

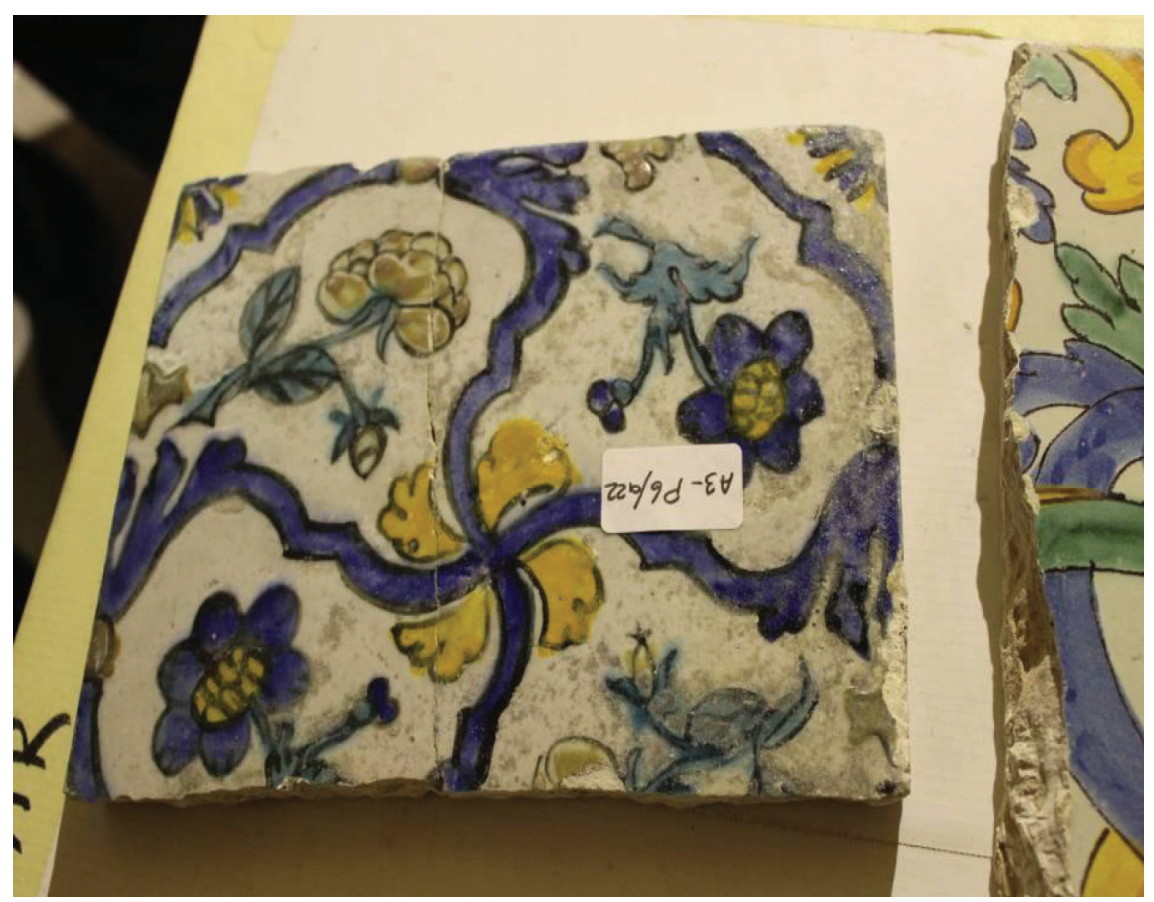

Resim 20. Ithal olması muhtemel çini levha

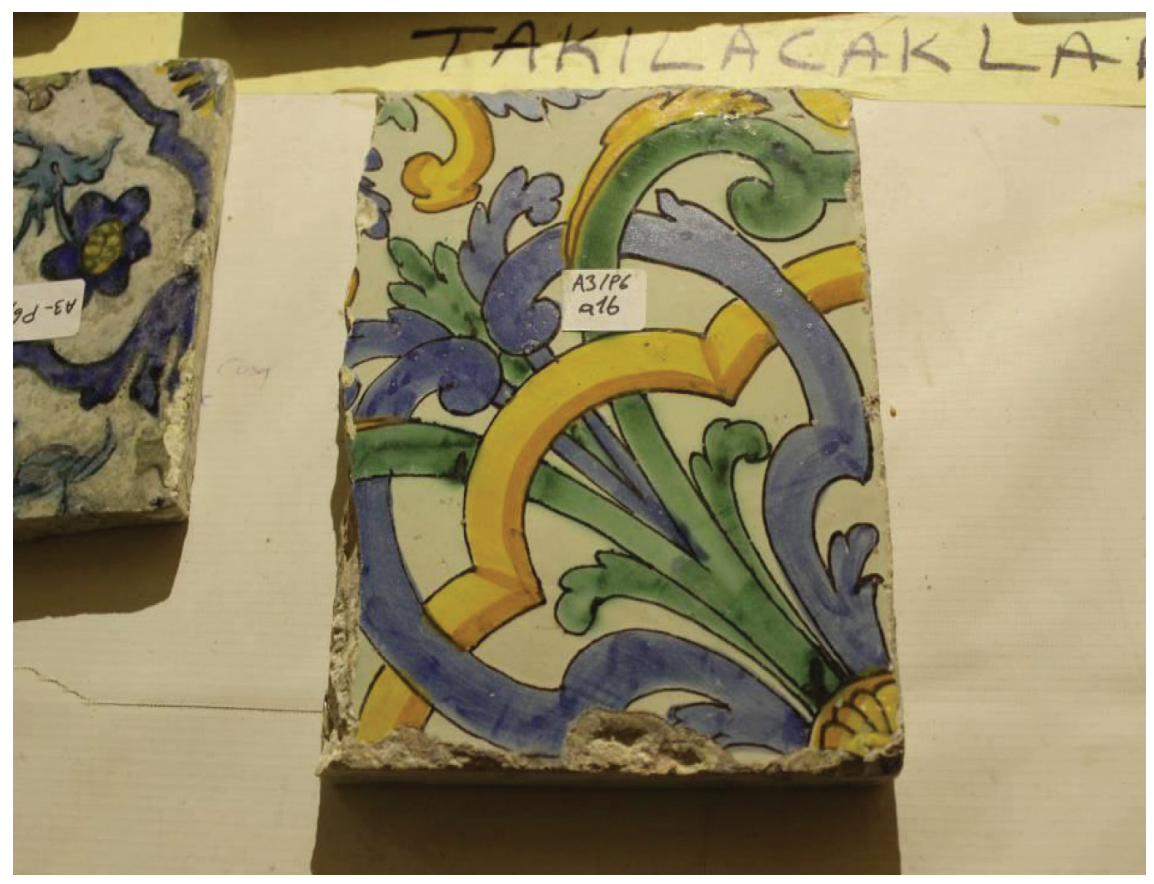

Resim 21. ithal olması muhtemel çini levha 